\title{
Work Hours Instability and Child Poverty: Response of the Safety-Net Programs †
}

Julie Cai

Center for Economic and Policy Research (CEPR)

(Version: 8/30/2021)

\begin{abstract}
This paper uses data from the Survey of Income and Program Participation to investigate how intra-year caregiver work-hours volatility is related to child poverty, measured through both the official poverty measure (OPM) and the supplemental poverty measure (SPM). I further assess varying degrees of buffering effects of cash benefits, in-kind benefits, and tax transfers on income in the context of work-hours volatility. Results indicate that Black and Hispanic children, as well as those living with unpartnered single mothers, faced substantially higher variability in household market hours worked. Hispanic children experienced not only greater volatility in their caregivers' work hours, but also higher poverty levels, even after taking government programs into account. I find that a 10 percent increase in intra-year hours volatility is linked to roughly a 2 percent and 1.6 percent increase in OPM and SPM child poverty, respectively. Inkind benefits are more effective in buffering household income declines resulting from unstable caregiver work hours, followed by tax transfers and cash benefits, which each offer somewhat less of a buffering effect. The effectiveness of near-cash benefits is particularly salient among Black children and children of unpartnered single mothers. Hispanic children also benefited from these transfers' compensating effects, but to a lesser degree. These results provide new evidence to inform public policy discussions surrounding the best ways to help socioeconomically disadvantaged families to retain benefits and smooth their income in the face of frequent variation in work hours and, thus, earnings.
\end{abstract}

$\dagger$ I thank Liana Fox, Lonnie Berger, Tim Smeeding, Chris Wimer, Dan Meyer, and Daniel Feenberg for helpful input on this draft. 


\section{Introduction}

Real GDP per capita increased by over 15 percent between early 2000 and 2016 in the United States. However, economic conditions for some groups, particularly lower-income families with children, remained stagnant during the same period (Shaefer \& Edin, 2013). The US child poverty rate has also remained relatively high by international standards; in particular, racial and ethnic minority children, as well as children living with unmarried parents, experienced higher levels of poverty than white children and those living with married parents (NASEM, 2019). This is despite increased female participation in the labor force and a high frequency of nonwhite mothers' employment, which has increased considerably over the past few decades. Prior research tends to attribute the paradox of a strong labor market and employment growth with simultaneously high poverty rates to a combination of low wages and chronic and persistent unemployment (Hoynes et al., 2006). Recent studies have increasingly described unpredictable labor market activities or the variability of family economic resources and sought to understand how they affect the well-being of families with children. However, the extent to which such instability itself — rather than families' average income levels over a year (or more) — is associated with child poverty remains unclear.

The term economic instability ${ }^{2}$ encompasses intra-family changes of economic resources, including those driven by changes in wages, work hours, and employment. When they are frequent and unanticipated, such changes are a critical dimension for understanding individual and family economic insecurity. Among various sources, earnings churn stemming from inconsistent employment and/or work hours is one of the leading causes of family income

\footnotetext{
${ }^{2}$ Instability and volatility are used interchangeably throughout the paper.
} 
variability (Finnigan, 2018; Morduch \& Schneider, 2017; Schmeiser et al., 2014; Western et al., 2016). Earnings volatility's implication for children is especially compelling, as it influences the material and emotional quality of parental care children receive. Earnings instability may cause income deficits or episodic poverty and subsequent parental stress that may negatively affect children's home environments and learning experiences (Hill et al., 2013; Yeung et al., 2002). These factors may obstruct children's long-term life opportunities or hinder their economic mobility (Hardy, 2014; Hardy \& Marcotte, 2020). Yet, while inconsistent earnings as a result of unstable employment or work hours is a key plausible source of household income instability, no national-level study has analyzed trends of within-year work-hours instability at the household level and how such volatility relates to child poverty.

Another related question that remains unanswered is how various elements of economic safety-net programs including direct cash transfers, in-kind transfers, and various aspects of the tax code respond to work instability resulting from changes in employment or work hours families experience within a given year. For example, research indicates that the fiscal stimulus measures during the Great Recession that expanded programs such as Supplemental Nutrition Assistance Program (SNAP) and Unemployment Insurance (UI), greatly benefitted lower- and middle-income individuals and families and prevented many from experiencing poverty (Bitler et al., 2016). At the same time, some safety-net programs' eligibility rules have been gradually tied to work, making them less responsive to families facing unstable earnings due to hours cuts or job loss issues (Hill \& Ybarra, 2014; Moffitt, 2013). Thus far, research on the effectiveness of safety-net programs has mostly focused on how they affect employment and income levels over a year or more (Wimer et al., 2020). We know relatively little about how such programs respond to within-year variation in earnings due to fluctuation in hours. 
This study investigates how intra-year work hours instability is associated with child poverty and provides evidence about how the redistributive effects of safety-net programs may counteract child poverty in the context of unstable parental work hours. Using a nationally representative sample of children under 18, this paper first descriptively profiles the intra-year instability in work hours that families with children experience, on the whole and across population subgroups defined by race/ethnicity and family structure, focusing on children from sociodemographic groups historically at greater risk of poverty. I then examine how household work hours instability over the course of a year relates to child poverty in the year using both the official poverty measure (OPM) and the supplemental poverty measure (SPM). Finally, I examine the extent to which cash, in-kind, and tax transfers may protect children in households that face frequent work hours changes from poverty. I pay particular attention to the role of transfer programs among female-headed households and nonwhite households.

\section{Background}

Few studies of the role of volatile parental work hours in children's lives exist at the national level, but two related areas of research exist. First, a growing body of literature has examined income volatility for individuals and households, with some studies focused specifically on households with children. Second, studies on short-term work-hours instability have focused on the unpredictability of hours worked, particularly in certain service sectors. To understand the link between work hours instability and child poverty, this section begins with a brief portrait of income volatility's and work instability's prevalence in the US and of heterogeneity therein by race/ethnicity and family composition. I then review the literature on how labor market factors and shifts in family structure are associated with children's income insecurity, as well as on social programs' response to economic instability. 


\section{Economic security among children}

As an umbrella term, “economic instability" captures households' frequent changes in income or employment, usually within a year or from year to year (Hill et al., 2017; Morrissey et al., 2020). Despite growing research on the income instability households experience over time, the incidence of work instability among families with children is underexplored, particularly in terms of within-year work hours variability. Research has consistently shown stagnant or slightly upward trends in total household or family income instability (Dynan et al., 2012; Gottschalk \& Moffitt, 2009; Hardy, 2017). Earlier research also suggests that earnings instability among males was rising (Gottschalk \& Moffitt, 2009; Haider, 2001; Shin \& Solon, 2011; Ziliak et al., 2011). In 2012, roughly 37 percent of a national sample of respondents self-reported that their income would not remain stable in the upcoming 12 months (Schmeiser et al., 2014). Children in these families inevitably face greater challenges regarding their developmental milestones. This is especially true for children at the lower end of the family income distribution, as they are about twice as likely to experience income instability as their high-income counterparts (Morris et al., 2012). Moreover, children of color face a consistently lower level of economic resources and more unstable intra-year parental income (Gennetian et al., 2019). Analyzing SIPP data from 1996 to 2004, Acs et al. (2009) illustrated that approximately 14 percent of parents at the bottom end of the income spectrum experienced a minimum economic shock of at least a 50-percent income drop over a given year; only half of them recovered their full income within the following year (Acs et al., 2009). Economic shocks were by far the most consistent factor impacting households' material well-being (Heflin, 2016). Across sources, unpredictable or involuntary changes in labor market status and/or varying work hours were among the forces contributing most to family income instability (Golden, 2015; Hill et al., 2013; Lambert, 2008; 
Morduch \& Schneider, 2017). However, no national-level study has attempted to uncover frequent changes in households' market hours worked and its link to child poverty.

Regarding frequent work hours changes, most research has focused on varying hours worked by people in certain occupations or in specific age cohorts instead of studying the broader national labor force. This is partly due to limited available data to quantify the variability of hours worked. For instance, Lambert et al. (2014) found that about 25 percent of retail workers had varying hours using a binary question about whether workers' weekly hours had changed. Using another measure- the maximum and minimum numbers of hours worked per week in the last month — nearly half of retail workers between the ages of 26 and 32 reported a difference of about 10 hours between weeks (Lambert et al., 2014). This was further confirmed in other studies using similar measures (Schneider \& Harknett, 2019). Focusing on a broader population, another study utilized a dichotomous variable regarding whether hours varied to estimate the prevalence of workers experiencing irregular hours based on nationally representative data and found that about 6 percent of wageworkers reported their hours varied between 2004 and 2013, which provides a lower bound estimate (Finnigan \& Hale, 2018). In addition, variation in work hours appears to be more common among unmarried workers than married workers, as well as among racial and ethnic minority workers and those in blue-collar jobs and in the services sector (Golden, 2001). It is also more concentrated among hourly wage earners than salaried workers (Finnigan, 2018).

Together, these studies provide a valuable portrait of economic insecurity among families and children, with two major limitations. First, despite a growing literature documenting household income instability's prevalence among families with children (and given that variation in earnings constitutes the main source of such income fluctuations), there is limited evidence on 
the extent to which work hours instability affects children's economic well-being. In other words, despite established links among persistent unemployment, underemployment, low wages and poverty, social scientists have yet to document how work hours variability is linked to poverty status, accounting for both between- and within-job work hours instability. Second, studies attempting to capture variability in work hours (whether using dichotomous variables and range calculations or weekly work-hour differences) have not yet been able to comprehensively profile unstable work lives longitudinally. For example, the binary variables in the Current Population Survey (CPS) data might largely understate the breadth of work instability problems (Finnigan, 2018; Lambert et al., 2014). Indeed, one recent study using CPS data examined the actual hours workers reported month-to-month and found substantially greater variability in hours worked among low-wage workers (LaBriola \& Schneider, 2020). The current study contributes to this line of research by providing the first estimates quantifying household market hours worked within a year in relation to income and poverty for families with children.

\section{Work hours instability and child poverty}

Historically, child poverty rates have been relatively high among single, female-headed, and nonwhite households and an extensive body of research has focused on parental underemployment, unemployment, and low wages. However, household work hours churn may also jeopardize children's economic well-being in these households. During the Great Recession, nearly nine out of ten children living below the official poverty line had at least one parent working either full or part time (Bauer et al., 2019), suggesting that either the income earned was insufficient to lift children out of poverty or that parents experienced intermittent unemployment or reduced hours. In fact, over the past few decades, labor market polarization and the prevalence 
of single motherhood often contributed to employment instability, triggering greater economic insecurity for children.

The US labor market structure has changed dramatically, with a significant increase of lowwage jobs (Autor \& Dorn, 2009). However, the fringe benefits associated with such jobs are meager, and workplace practices often do not meet workers' needs. Low-wage jobs are characterized by stagnant pay, unpredictable working hours, last-minute scheduling, and little or no employer benefit packages (Alexander \& Haley-Lock, 2015; Kalleberg et al., 2000). These conditions inevitably increase rates of turnover and deteriorate the economic circumstances of low-income workers and their families. Nonwhite workers are predominantly represented in these unstable occupations (Golden, 2001). Hence, labor market churn likely translates to poorer outcomes for nonwhite children.

Along with labor market polarization, family configurations have exhibited a diverging pattern. Lower-educated single females, on average, have their first child in their early 20s, and lower-educated mothers are now highly likely to be working (McLanahan, 2004, 2009). Single mothers with children under age 6 experienced the most dramatic increase in their employment rates in the early 2000s (Cancian \& Reed, 2008). Although most single mothers work (Cancian \& Haskins, 2014), most work at low-wage jobs with unstable hours or job security, triggering frequent turnover (Hollister, 2011; Lambert et al., 2014)—especially in a context of competing demands for caregiving duties. Therefore, children's experiences resulting from work instability may differ significantly across various family configurations.

Although resources are generally aggregated at the household level, the number of earners in a family and how they prioritize home life by negotiating job schedules also matters. In singleparent families, children living with a parent who works part time or who has an irregular 
schedule might face low quality or inconsistent childcare. This often occurs because singleparent families are more financially disadvantaged (Conger \& Conger, 2002). Hardy (2017) estimated that single-parent families have more volatile economic conditions regardless of preor post-transfer income. Conversely, in nuclear or cohabiting families with dual-earner parents, if one caregiver begins working part time, is on call, or is laid off, the family may avoid some disadvantages via resource pooling and time sharing between the two adults. In some cases, the two adults may work with distinct schedules to care for a child on an alternating schedule (Deutsch, 1999). To this end, this paper adds knowledge to better understand employment instability and child poverty by distinguishing patterns by family structure.

\section{Policy response in the context of economic instability}

Government income-support programs, through direct cash and in-kind transfers and indirect transfers through the tax system are a major economic safety net for many low- or moderate-income individuals and families. Government assistance programs range from cash income programs like UI, Temporary Assistance for Needy Families (TANF), and general assistance to near-cash programs, such as SNAP, Special Supplemental Nutrition Program for Women, Infants and Children (WIC), and housing subsidies. UI spending has increased significantly since 2007 (Moffitt, 2013), protecting many individuals from falling into poverty during the period (Bitler \& Hoynes, 2016) and expansions to federal programs, most notably SNAP and the Earned Income Tax Credit (EITC), were particularly generous during the Great Recession (Bitler \& Hoynes, 2016). However, the extent to which these safety-net protections stabilize or offset frequent employment churn remains unclear.

In recent decades, government safety-net programs have shifted from cash-based benefits to near-cash programs and have become more employment-conditioned (Hardy, 2017; Hill \& 
Ybarra, 2014; Moffitt, 2013). This approach might provide intermittent receipt of benefits because income earned via employment may be required when applying for benefits or recertification (Hill et al., 2017). Frequent job churn and unstable working hours can hinder families trying to maintain a consistent work history or earnings. On one hand, they may lose certain benefits if their earnings exceed the eligibility threshold when work hours increase, even though this may be temporary. On the other hand, how quickly they can access benefits when hours go down or they lose their jobs is unclear.

A few studies have examined the impacts of individual programs or the overarching safety net in the context of work hours instability. Evidence points toward in-kind benefits-SNAP in particular-as effectively stabilizing income when earnings volatility or income shocks occur (Gundersen \& Ziliak, 2003; Hernandez \& Ziol-Guest, 2009). Less is known about the extent to which cash-assistance programs, such as UI or TANF, play similar roles. More generally, recent research suggests that governmental transfers play a more significant role in raising average household incomes than in buffering against intra-month income fluctuations (Morduch \& Siwicki, 2017). One recent study assessed the safety net's impacts on mitigating year-to-year income instability and suggested that safety-net programs have become less responsive to the economic needs of disadvantaged families (Hardy, 2017). No prior research has emphasized safety-net transfer programs' role in intra-year work hours instability.

Another potentially compelling reason to study the safety-net's response to unstable work hours in the context of child poverty, as measured by the SPM, is that it highlights transfers through the tax system. As income-support programs' eligibility becomes relatively tied to employment, for example, EITC serves as one of the core sources for low-income families to save, pay off debts, and purchase goods (Halpern-Meekin et al., 2015). More child-friendly tax 
credits, like refundable child tax credit (CTC), may help lessen part of the adverse financial consequences from work hours (and associated earnings) churning. Moreover, childcare expenses eat up a nontrivial portion of the monthly budget for low- and middle-income families. Taking into account necessary expenses, including childcare cost, is important to better understand the actual economic well-being of a child's family in the face of discretionary disposable income.

To this end, this paper extends the existing literature by utilizing a nationally representative dataset with detailed information on intra-year employment and various income sources and expenditures. I then couple these data with estimations of household tax liability and credits. Using OPM and SPM calculations of child poverty allows for a comparison of how much in-kind benefits, tax liabilities or credits, and necessary expenses matter for child poverty in the face of within-year unstable caregiver work hours. The study also aims to assess and contrast the separate buffering effects of cash, in-kind, and tax transfers on economic well-being among children facing unstable caregiver employment.

\section{Data and Method}

The study uses data from the Survey of Income and Program Participation (SIPP), a nationally representative data set well known for its comprehensive information on household income, earnings, program participation, and socio-economic status. The SIPP is well suited to investigating instability-relevant questions and has been used in research on income instability in various disciplines. Because family economics are quite dynamic and labor market states change rapidly, the SIPP's short-term, four-month-interval interview panel design, in which respondents provide information on work activity in the corresponding interview interval, enables researchers to map trends of within-year employment instability over time. Each panel of the SIPP 
interviews the same group of respondents every four months and covers extensive information about the prior three months as it relates to sociodemographic characteristics, labor market factors, income, and social program participation at the individual or household level for each person in the household. While households' tax liability or credits are unavailable in the SIPP, I use the NBER TAXSIM to estimate tax liabilities.

Although each four-month interview includes retrospective reports on many items for the previous three months, the question pertaining to the average number of hours worked for all jobs refers to the whole four-month period. Therefore, only the record at the time of interview (i.e., the fourth-reference month) is selected at each wave to form the analytic sample. That is, for each respondent, the analytic sample includes a maximum of three records per year. Each panel spans a three- or four-year period. This paper selects data from SIPP 2004, 2008, and 2014 panels covering the period from 2004 to 2016. Adopting a child-focused perspective, the study restricts the sample to households in which a child lives to those where (a) the head of household was a working-age adult (ages 19-64); and (b) at least one member in the household was working during the year. The sample contains about 87,508 child-year observations. To improve national representativeness, the subsequent descriptive results reported are weighted using the longitudinal calendar year weights.

Work hours instability. The study conceptualizes work hours instability as wave-to-wave variability in hours worked over a year. To arrive at a volatility index of working hours across a year, I calculate the weekly work hours reported at each wave for each household member to arrive at the total hours worked for the entire household in the given wave. I then measure the intra-year work hour volatility as the standard deviation of the arc percent change of total work 
hours across a year. This is operationalized in the following form: $v_{i}=\sqrt{\operatorname{var}\left[\frac{H R s_{i t}-H R s_{i t-1}}{Y}\right]}$ where $\mathrm{v}_{\mathrm{i}}$ is the volatility index for household $\mathrm{i}$ in a given year. $\mathrm{HRs}_{\mathrm{it}}$ denotes total hours worked for child i's household at wave $t$ in a given year. The denominator, $\mathrm{Y}$, uses a midpoint approach in order to reduce the impact of large changes in total hours worked between waves. This measure has been utilized in prior studies on income instability (see Dynan et al., 2012; Hardy, 2017; Ziliak et al., 2011). The approach allows people with waves of zero working hours to remain in the sample due to the midpoint measure. As a sensitivity check, I also calculate the volatility as the coefficient of variation of working hours, an approach by Newman (2008) and Gennetian et al. (2015). I use the natural log of the instability in subsequent models.

Outcomes. There are six dependent variables of interest in this study. The first two are dichotomous variables - child income poverty (including both the official poverty measure $[\mathrm{OPM}]$ and supplemental poverty measures $[\mathrm{SPM}])$ - which are measured over the year, so that I can address whether intra-year volatility in hours worked is linked to annual child poverty status. OPM is the official federal statistic, defined as a family's total pre-tax cash income falling under a specific threshold that is about three times the cost of a minimum food diet in 1963 (Semega et al., 2019). I first calculate income-to-needs ratios by dividing gross before-tax income by the threshold for the given household based on the size and composition. If the income of the household where a child lives is less than 100 percent of the relevant poverty line, then the household is classified as living in poverty and, therefore, assigned a value of 1; otherwise, it is assigned a value of 0 .

The determination of a child's SPM poverty status follows a more sophisticated process to construct a new family unit, economic resources including expenses, and the according 
thresholds based on the child's family size or composition, housing tenure, and geographic location. I describe major elements in this section (see Fox [2019] for more details). Building upon the family-unit definition under the OPM, the SPM measure adopts a more inclusive concept of family that further includes unmarried partners, their relatives, foster children, and coresident unrelated children younger than 18 .

To expand its thresholds, to consider geographical adjustment and housing tenure types, I first use five-year moving average data from the American Community Survey (ACS, [accessed through IPUMS]) to calculate the median gross rent for a two-bedroom apartment by metropolitan statistical areas (MSAs) and non-MSAs for each state. I also create a three-category indicator denoting households who own their homes with mortgages, own their homes without mortgages, or rent their units. Coupled with the three SPM-based thresholds calculated based on housing tenures by the Bureau of Labor Statistics Division of Price and Index Number Research from the Consumer Expenditure Survey (CE), I then adjust the housing portion of SPM thresholds to account for geographic differences in housing costs across the country. Last, given varying levels of needs based on different family compositions, I use a three-parameter equivalence scale to account for economy of scale (see Fox et al., [2015] for details).

Under the SPM measure, economic resources reflect a more realistic understanding of the discretionary income a family may have to meet basic needs. These resources include not only cash income but also near-cash transfers, netting out taxes (plus tax credits) and subtracting any necessary expenses. In the present study, cash income includes earned income, investment income, and means-tested cash transfers (i.e., UI, SSI, TANF, General assistance). Near-cash transfers considered in the study include large federal programs designed to help low-income families meet their basic needs, namely SNAP and WIC programs. Monthly dollar amounts for 
SNAP and WIC are collected in the SIPP; however, housing subsidy receipt is merely a monthlylevel dichotomous variable denoting whether a child's family receives assistance from housing voucher programs or lives in public housing. Following Fox et al. (2015)'s approach, I estimate the value of housing subsidies a child's family receives each month by first calculating annual fair market rents (FMRs) for specific states by metropolitan or nonmetropolitan areas in which a child resides. I then subtract 30 percent of a family's income from the corresponding FMR to arrive at the subsidy amount. Following Fox et al.'s work further, the subsidy values are capped at 89 percent to avoid overstating the dollar amount for housing assistance. The monthly values are then summed across 12 months and added to the non-cash transfers. Similarly, SNAP and WIC are also summed separately over the 12-month period by the SPM family unit. As the SIPP does not collect information about the amounts of taxes each respondent paid, I use NBER's TAXSIM 32 to simulate tax payments or credits. The simulations include federal and state income taxes and social security payroll taxes. Taking into account tax liabilities also allows factoring in credits received, such as EITC and refundable CTC. Lastly, the SIPP includes most of the expense items required to calculate disposable income. The expenses considered necessary in the study include out-of-pocket medical expenses, child support payments, childcare expenses, and work-related expenses (e.g., commuting cost). These items can be found in the topical modules prior to the 2014 panel.

To ensure the accuracy of the SPM construction, I use reported rates (2013-2016 average based on the 2014 SIPP panel from Warren et al., 2020 and the CPS ASEC [accessed through IPUMS]) as a benchmark to compare my results. Despite further restriction in the current analytic sample, I start with the raw dataset so that all respondents can form a comparable sample with others' estimates. Overall, the results are quite consistent. For the total population 
(pooling 2013-2016 data), the total poverty rates are about 14.5 percent for both OPM and SPM measures, with the SPM rate being slightly higher than the OPM rate is. With respect to race/ethnicity, SPM rates among Whites, Blacks, and Hispanics are 13.2, 20.8, and 22.9 percent, respectively; these are relatively consistent with Warren et al.'s 13.4, 20.2, and 22.4 percent estimates. For children, the average OPM poverty rate from 2013 to 2016 is nearly identical, at about 20.5 percent, for both my estimate and that of Warren et al. (2020). However, the SPM child poverty rate in my raw sample is about 17.4 percent compared with the 15.8 percent that Warren et al. reported. This is likely due to the exclusion of the school meal program and the Low-Income Home Energy Assistance Program (LIHEAP) in the current calculation. The school meal program has particularly been shown to lift a number of children out of SPM poverty during this four-year period (Short \& Giefer, 2013). Another way to verify this is to compare the child SPM poverty rate in the CPS, which also does not account for the school breakfast program. Indeed, the child SPM poverty rate has been reported at 17.2 percent, very close to my estimate of 17.4 percent. Warren et al. (2020) also attributed the difference in the SPM child poverty rates between SIPP and CPS to the school meal program. In addition, the 2014 SIPP panel only has information on whether the respondents' households participated in the LIHEAP programs over the course of the year and whether subsidies were paid directly to a household. The present study does not proceed to impute an annual amount received from the energy assistance program.

The other four dependent variables are continuous income variables that reflect the disaggregation of economic resources for the SPM (see Appendix Table A2 for details). These comprise four versions of household income packages, which are measured for the full year, because the primary focus is to address the extent to which cash, in-kind benefits and tax 
transfers might buffer the negative consequences of intra-year volatility in hours worked on income. First, market income consists of a household's earned income, property income, and lump-sum payments and self-employed income over the course of the year. Second, I add total cash transfers received in the year (including TANF, SSI, GA, and UI) to market income. Third, non-cash income in the form of in-kind benefits (e.g., SNAP, WIC, and housing subsidies) is factored in. The last outcome measure considers tax payments and refunds to calculate posttransfer, post-tax income for a child's household. All income is adjusted for inflation and converted to 2013 dollars and is log-transformed.

I perform subgroup analyses based on two other key variables: race/ethnicity and family structure. Information on a child's race/ethnicity comprises whether they are non-Hispanic White, non-Hispanic Black, Hispanic, or other. Regarding family configuration, in each core module of the SIPP, a detailed household relationship variable is provided, which indicates each household member's relationship to the head of household. This serves as a focal point for each wave, where I infer each member's relationship to the child in the household. I conceptualize family structure by considering whether both parents were married and present, and whether social (step) parents are present in the households who are cohabitating. This results in six mutually exclusive categories: (1) married-parent family, (2) single mother and partner, (3) single mother, (4) single father and partner, (5) single father, and (6) neither parents present. It is worth noting that a child's family structure could vary within a year and that this should affect work hours instability through the number of potential workers in the household, regardless of changes in hours workers experience in the labor market. As such, I construct family structure as time-invariant measure based on initial observation. I then consider indicators at each wave that the child experiences no change in adult caregivers (mother/father and spouse or partner; 
reference category), gained adult caregiver(s), and lost adult caregiver(s). As the analyses are based on child-year observations, I include a set of dummy variables denoting whether a child ever experienced both an increase and decrease in adults in the household over the year, ever experienced an increase in adults only, ever experienced a decrease in number of adults, and never experienced gain or loss in adults.

Covariates. Most basic family characteristics are derived from the baseline (first wave) interview. These include parental education (less than high school, high school diploma, some college, and college or higher education); parental age (19-25, 26-40, 41-55, and 56-64); child's age (1-5, 6-12, and 13-17); whether a child experiences changes in the number of adults in the household across waves within a year; family size (number of household members); and parental occupation types (management or professional, services, sales, office jobs, and blue-collar occupations).

\section{Analytic Strategy}

I use linear regressions to model whether volatility in hours worked is predictive of income and child poverty and assess the extent to which cash payments, in-kind benefits, or tax systems may buffer the adverse consequences of work-hour volatility. I initially used two specifications to estimate linear models with controls for the forementioned child and parent characteristics, without or with state and period fixed effects. However, because the results were quite consistent across specifications, only results with the full set of covariates are reported.

$$
\left.Y_{i}=\beta_{0}+\beta_{1} \text { (Instability) }\right)_{i}+\beta_{2} X_{i}+\delta_{i t}+\gamma_{s}+\varepsilon_{\text {ist }}
$$

where $Y_{i}$ is child i's household's outcome measures of interest, including (1) OPM child poverty, (2) SPM child poverty, (3) market income, (4) market income plus cash benefits, (5) market income, cash, and non-cash benefits, and (6) post-transfers and tax income. $\beta_{1}$ is the 
coefficient indicating the effect of instability in work hours on the outcome, and the main interest of the current study. $\mathrm{X}_{\mathrm{i}}$ is a vector of covariates mentioned above, and $\delta_{\mathrm{t}}$ denotes a set of year fixed effects. $\gamma_{s}$ is a set of state indicators. To understand better the varying degrees of the effects each income source can have on counteracting household income declines, I computed the proportions of mitigating effects for cash, in-kind, and tax transfers, respectively. For instance, $\beta_{m k}, \beta_{m k+c a s h}, \beta_{m k+c a s h+\text { inkind }}$ are the effects of work-hour instability on a child's various income packages, measured accordingly by percentage changes. I applied $\left(\beta_{m k}-\right.$ $\left.\beta_{m k+c a s h}\right) / \beta_{m k}$ to arrive at the proportion of income decline buffered by cash transfers. Similarly, $\left(\beta_{m k+c a s h}-\beta_{m k+c a s h+i n k i n d}\right) / \beta_{m k+c a s h}$ enables calculation of the proportion of income reduction resulting from work-hour instability that is compensated by the in-kind benefit.

In addition to the overall sample, these models are replicated among each subgroup. By comparing and contrasting the estimated coefficients between different income models, I can assess the magnitude of the work-hour volatility in predicting different versions of household income, which would signal the extent to which social benefits can offset the negative effects of precarious work on specific groups, such as racial minority children and children living in households with single mothers who have no partners present.

\section{Results}

\section{Descriptive results}

Table 1 reports overall summary statistics for the full sample and separately by race/ethnicity, pooling data from 2004 to 2016. Slightly more than half of sample children are White, and Black and Hispanic children make up the other 13 and 25 percent of the sample, respectively. The remaining 9 percent are Asian, Native American, or multi-racial children. The average work hours volatility across the sample is about 0.28 , indicating that, on average, sample 
two-parent households experience variation of about 15 to 20 total work hours between fourmonth interview waves. White children experience about 11 percent less household work hours instability than the sample average, and Black and Hispanic children, on average, experience about 25 percent and 7 percent higher instability than the sample-wide average, respectively. Turning to the first two key outcomes, we see a much lower poverty rate under the SPM (18 percent) compared with 20 percent under the OPM. This difference most likely stems from the lower SPM rates for nonwhite children. Among Black children, for example, 19 percent are under SPM poverty, whereas 31 percent are deemed to live under the official poverty line. Hispanic children have strikingly high poverty rates, regardless of which measures are used. White children are an exception, as they have nearly a 2 percentage point higher SPM poverty rate relative to their OPM rate. Looking specifically at various income sources, on average, the market income for a child's household is about $\$ 73,000$. Black and Hispanic children have less than three-quarters of average market income sample wide. However, when cash transfers are factored in, Black children have only a 27 percent lower household income relative to the sample average, as opposed to a 29 percent lower market income. After accounting for near-cash transfers and tax, this difference is reduced to about 22 percent. Hispanic children see a similar pattern but to a lesser degree.

Regarding family structure, Black children are less likely to live with two biological parents. Instead, they are overrepresented in single-mother households without partners present, at 46 percent, compared with 18 percent among the total sample. Hispanic children disproportionately live with parents with less than a high school diploma or GED and have one parent working in a blue-collar occupation. In addition, Black and Hispanic children tend to live with at least one parent working in a service-related occupation. 
Table 2 presents descriptive results, stratified by the base family structure in which a child resides. One merit of the paper is to further identify whether a single parent is living with or without a partner in the household, as this nuanced distinction in living arrangement may have implications for a child's economic well-being. About 18 percent of children live with a single mother without any partner present in the household (although other relatives may still be present in the household); 4 percent live with their mother as well as their stepfathers; and 8 percent live with unmarried fathers regardless of partner presence. Although children in nuclear families face lower levels of caregiver work-hours instability, all other children residing with single parents have higher levels of hours instability regardless of their parents' partnership status. Those living with single mothers without or with partners present have roughly 36 and 18 percent higher work hours volatility relative to the average. Children with single fathers face a 14 percent higher variability of work hours. Despite a strikingly higher OPM poverty rate among children living in single-mother households, it is quite promising that governmental near-cash and tax transfers reduce child poverty by half among those living with single mothers who are partnered. These programs also lift two out of five children out of poverty, specifically those living with unpartnered mothers. This is also reflected in the post-transfers resources, which rose by about 10 percent from cash income measures for children in unpartnered single-mother households. These children are far more likely to have one parent working in the service sector. By contrast, children in nuclear families or living with unpartnered single fathers see a larger decrease in post-tax and transfer household income relative to cash income. Children from single-father households tend to overwhelmingly have parents holding blue-collar jobs.

Figure 1 depicts the raw child poverty rates during the period examined, as well as the prevalence of caregiver work-hour volatility among children. Denoted by the solid line, volatility 
in hours for all children increased by 29 percent from 2004 to 2010 and remained elevated for the following two or three years before it decreased to 0.27 around the 2014 period. It then showed an uptick in 2016, which is still higher than the average prior to the Great Recession. The long dash and short dash lines represent the OPM and SPM child poverty rates, respectively. The two versions of poverty rates seem to have diverged since 2004, with the OPM rate climbing to a peak of about 23 percent in 2012 before declining gradually. In contrast, the SPM child poverty rate tended to trend downward throughout. This may likely reflect the robust spending of safety-net programs during the Great Recession, effectively protecting families with children from falling into poverty.

The level of work hours instability rose a bit around 2005 and decreased around 2009. The exact reasons driving this are unclear, but long-term unemployment may have become more prevalent than volatile labor market churn did during the downturn, whereas hours fluctuated more when the economy gradually boomed and some parents started holding multiple jobs with varying hours of work. In addition, the 2000s saw a drastic decline in manufacturing jobs. That said, hours volatility is relatively stable when one pools data for each panel as seen in Appendix Table A1, where the summary statistics are presented across three panels. Table A1 also reveals that cash transfers, especially in-kind benefits, substantially increased during the Great Recession as evidenced through the 2008 panel compared with other panels. Tax programs also seem to be more protective with regard to the Great Recession.

\section{Regression results}

Table 3 reports linear models with robust standard errors predicting each outcome. The first set of results (Models 1 and 2) indicates that a 10 percent increase in work-hour volatility results in about a 0.4 percentage point ( 2 percent) increase in the probability of being OPM poor. This 
estimate drops to a 0.3 percentage points increase (1.6 percent) when the SPM measure is used. To further understand the driving forces linking hours volatility and poverty, I estimated four models where the different income measures were regressed in sequence on the same set of covariates. Recall that I model the income measures and work hours volatility in logarithmic form. Starting with market income, children in households with 10 percent greater hours volatility have about 1.5 percent less market income (Model 3). Income is about 1.3 percent less with 10 percent greater work hours volatility if cash transfers are counted (Model 4). When means-tested, near-cash benefits and governmental taxes are incrementally considered, the income decline for each 10 percent increase in hours instability appears to be 0.9 and 0.7 percent (last two models). Thus far, the largest contributing mitigating effects of safety-net programs seem to be from the in-kind programs, by about 31 percent, followed by tax programs, by about 22 percent.

As shown in the descriptive results, children of color face higher variability in household market hours worked. Black children, however, show a substantial reduction in SPM poverty relative to OPM poverty, whereas the SPM poverty rate for Hispanic children is more similar (see Table 1). This motivates further examination of the roles that various income components play in buffering the economic consequences of volatile hours for each group of children. Thus, I re-estimated the full set of four regressions, in which four income definitions were regressed for each of the subsamples stratified by race/ethnicity. To improve our understanding of the degree to which the newly factored-in income sources enhanced or offset the decline in each income package, I present, in Figure 2, the proportions of the income reduction as a result of hours instability that are buffered by cash transfers, in-kind transfers, and post-tax levels, respectively (see Method section for details). The first panel in Figure 2 reports results for the entire sample 
that are derived from the last four models in Table 3. This is followed by analysis of each subgroup: Black, Hispanic, and White children (see Appendix Table A3 for all corresponding models). Across the board, Black children seemed to experience greater economic buffering due in particular to near-cash programs, as well as cash programs. When one only considers market income plus cash benefits received, for each 10-percent increase in hours volatility, cash benefits could buffer about 19, 23, and 13 percent of the resulting income reductions for Black, Hispanic, and White children, respectively. Among Black children, 54 percent of the income decline associated with a 10-percent increase in hour volatility is offset by in-kind transfers. This is over twice the effects that cash benefits make. It is also promising to see that 17 percent of the remaining income drop is compensated at the post-tax level. For Hispanic children, government in-kind program' mitigating effect is nearly twice as large as cash transfers, but the tax system appears to be less effective to further protect them from household's income decline that is due to work instability. One finding worth mentioning is that although White children see a relatively low poverty rate, means-tested, in-kind benefits and tax programs seem to substantially buffer the economic consequences for Black children relative to their White peers.

Akin to Figure 2, Figure 3 presents the buffering effects that various income components (cash, near-cash, and taxes) can create in response to income decline caused by work hours variability. The results are structured by each family configuration in which a child resides (see Table A4 for the four sets of models). Specifically, for each family structure, I estimated four models separately regressing four income definitions (starting with earnings and incrementally adding cash, near-cash, and taxes) on the key predictor and full set of covariates. Again, the mitigating effects from in-kind programs stand out, with 54 percent for children living with unpartnered, single-mothers and 36 percent for those with cohabiting parents. Not surprisingly, 
cash program plays a larger role on single-mother households. Among children living with unpartnered, single mothers, cash programs compensate for the income decline that is due to work instability by about 19 percent. At a slightly lower level, such impact for single fathers with partners present is less than half the effects near-cash programs make. Although these income gaps associated with hours volatility are slightly further attenuated when taxes are considered, the offsetting effects from tax seem to be quite muted among single-mother households. The role that tax programs make on single-father households without partners and cohabiting fathers appear to mirror each other, at 20 percent. Conversely, among children from nuclear families, the roles of various transfer programs in buffering the income drop associated with increasing variability are quite modest.

I also use the alternative measure (CV) of hours volatility as the predictor and replicate the models in Table 3. As shown in Appendix Table A5, the relationship between work-hours variability and child poverty status, as well as other measures of economic well-being, operates in the same direction. The point estimates for OPM and SPM poverty outcomes are identical. The elasticities between hours volatility and different income packages appear to be slightly higher when I use the CV approach, but it is merely a 0.01 difference. Thus, estimates using each approach yield consistent conclusions.

\section{Discussion and Conclusion}

Prior studies have focused on income insecurity as a critical dimension for profiling economic instability experienced by households with children and have identified earnings instability (through changes in either between- or within-job hours) as one of the driving forces for income instability. Research has also suggested that since the late 1990s and early 2000s, income-support programs gradually have incorporated work requirements into the programs' 
eligibility criteria; therefore, the benefits may be contingent on employment. Given the persistently high child-poverty rate in the US, drawing on insights from both lines of research, this study complements the literature by investigating how household work-hours volatility is associated with child poverty and the extent to which the redistributive effects of cash, in-kind and tax programs can buffer income declines resulting from work-hours volatility. I pay special attention to the effectiveness of these programs among subgroups of households with children based on family structure and race/ethnicity. Four main findings emerge.

First, Black and Hispanic children, as well as those living with unpartnered single mothers, face substantially higher variability in household market hours worked. Among these children, Hispanic children also experience higher levels of poverty, even taking into account government transfers, while income-support programs seem to reduce poverty levels quite considerably for Black children and children with single mothers. Second, within-year caregivers' work-hours instability is significantly linked to child poverty, regardless which measures are used. The trend of work-hours instability seems to correspond relatively more closely to the trend of the OPM rate rather than to the SPM rate, suggesting that government spending on non-cash programs may offset some of the adverse impacts of unstable hours. Third, in-kind benefits (including SNAP, WIC, and housing subsidy) seem to be more effective in cushioning household income declines resulting from unstable caregiver work hours, followed by tax transfers and cash assistance, which each offer somewhat less of a buffering effect. Last, the effectiveness of nearcash transfers is noticeable particularly among the children of single mothers without partners and Black children. Hispanic children also benefitted from the compensating effects of the transfers but to a slightly lesser degree. 
The implications of these findings are especially relevant in a time when tackling child poverty and promoting family economic security are once again top priorities in the country. With an increasing number of low-income mothers entering the labor force, many will inevitably be exposed to the low-wage labor market, in which parents experience more volatility in terms of both the risk of layoffs or unemployment and instability in the number of hours or shifts worked. These results reveal that cash transfers' buffering effects are much more muted relative to the impacts from the in-kind programs and tend to be less responsive among subgroups, such as children with single fathers. This may reflect the fact that although social-insurance programs like UI ease financial stress when parents face job losses or persistent unemployment, they may not work well in the context of frequent employment instability. UI eligibility requires at least half or a full year of being employed before filing the application, and applicants must have lost their jobs through no fault of their own. Parents may not qualify for UI if they are experiencing intermittent employment or, in an extreme case, if single mothers who have no other adults to help with childcare must quit their jobs voluntarily and rely on temporary jobs that allow them to manage their caregiving duties. In addition, despite being a cash program, TANF is tied to work or training-to-work eligibility criteria, and it currently reaches very few eligible families.

Instead, substantial buffering effects against income drops are found in connection with near-cash programs, particularly among historically underserved subgroups. Although housing subsidies and WIC may play a large role in these mitigating efforts, SNAP is considered a robust program among families' in-kind income packages. Good reasons exist to believe this is the case, given its relatively high up-take rate and that it is not attached to employment conditions. This result confirms prior research documenting SNAP's response to income instability. In addition, the modest response of the tax programs shown in the findings raise questions on how transfers 
through tax codes, particularly items relating to children, could better smooth families' economic swings resulting from unstable intra-year employment. As a powerful anti-poverty policy, EITC has proved to boost low-income mothers' employment and ease income insecurity to some extent. However, if a low-wage parent involuntarily works reduced hours, thus resulting in lower take-home pay, then it might affect the size of the benefits. Also, this program, coupled with the CTC, is a one-time transfer, making it hard to swiftly offset any negative financial shocks that families experienced from the labor market. Monthly child allowance could address some of the issues constructively (NASEM, 2019). In light of this, the forthcoming 2021 advance CTC payment is promising. If it were to be implemented and be in place until 2025, it may bring positive outcomes for children in the years to come.

Just as important as government income-support programs, other family-friendly policies are worth mentioning. Some of the most pervasive causes of employment instability are involuntary, such as employers reducing the number of hours an employee can work to save administrative or labor costs (Appelbaum et al., 2003; Kalleberg, 2013; Lambert, 2008). Parents may also have to work fewer hours or drop out of the labor force to care for children or other family members. Therefore, policies like affordable quality childcare and paid leave may reduce economic swings. In the same vein, from the employers' side, enforcing provisions such as minimum hour guarantees and requirements for advance notice on hours is critical. Currently, only a handful of locales have implemented fair scheduling laws. The absence of nationally mandated workplace protections for guaranteed minimum hours may put extra burden on low- or moderate-income parents who are weathering economic insecurity in the labor market.

This study has several limitations that should be considered in contextualizing its results. First, the near-cash programs used in the study to produce the SPM are not comprehensive. 
School meal programs and LIHEAP were left out of the calculation because data on participation and benefit amounts were not consistently available across panels. If these programs had been included, more robust buffering effects of the in-kind portion of the safety net programs may have appeared, especially given the crucial role that school breakfast programs play for children's economic wellbeing. More research is needed to confirm whether varying degrees of redistributive effects of public policies can compensate for intra-year work instability. It will also be beneficial for future studies to understand how a monthly child allowance may lessen the negative financial consequence of employment instability on children's economic wellbeing. Second, as some earlier studies have pointed out, varying numbers of hours worked and frequent unemployment spells are both tenable sources of economic insecurity. The present study does not distinguish between these two. Instead, variability in total work hours could be a function of changing jobs or earnings and of within-job changes in work hours. Further studies are warranted to unpack these two aspects of earnings instability by disentangling the unique roles of withinjob and between-job instability and their effects on child poverty. In addition, it may be worth investigating how the magnitudes of the buffering effects on within-year work instability from different components of safety-net programs evolve over time. Finally, it is important to note that, whereas the study focuses on within-year work hours volatility, it considers only annual poverty. As such, it is silent on whether families experienced intermittent poverty over the course of a year even if their total annual income exceeded the OPM or SPM threshold for the year.

With this in mind, the study expands the ongoing literature on children's economic (in)security. Although intra-year work hours instability is significantly related to child poverty, government program response-near-cash transfers, in particular-proved to be quite effective in counteracting income loss. This is more pronounced for certain subgroups of children, 
particularly Black children and those living in single-mother families. Additional steps should be taken to rethink how other programs in the modern work-based safety net could smooth income more effectively in the context of intermittent or precarious employment, so that income support, aside from employment support, can make a real difference in children's economic lives. 


\section{References}

Acs, G., Loprest, P., \& Nichols, A. (May 2009). Risk and Recovery Documenting the Changing Risks to Family Incomes. Urban Institute. Retrieved from https://www.urban.org/sites/default/files/publication/32966/411890-risk-and-recoverydocumenting-the-changing-risks-to-family-incomes.pdf

Alexander, C., \& Haley-Lock, A. (2015). Underwork, Work-Hour Insecurity, and A New Approach to Wage and Hour Regulation. Industrial Relations: A Journal of Economy and Society, 54(4), 695-716. https://doi.org/10.1111/irel.12111

Appelbaum, E., Bernhardt, A. D., \& Murnane, R. J. (Eds.). (2003). Low-wage America: How employers are reshaping opportunity in the workplace. Russell Sage.

Autor, D. H., \& Dorn, D. (2009). Inequality and specialization: the growth of low-skill service jobs in the United States. NBER Working Paper Series, 15150.

Bitler, M., \& Hoynes, H. (2016). The More Things Change, the More They Stay the Same? The Safety Net and Poverty in the Great Recession. Journal of Labor Economics, 34(S1), S403-S444. https://doi.org/10.1086/683096

Bitler, M., Hoynes, H., \& Kuka, E. (2016). Child Poverty, the Great Recession, and the Social Safety Net in the United States (No. w22682; p. w22682). National Bureau of Economic Research. https://doi.org/10.3386/w22682

Bauer, L., Moss, E., \& Shambaugh, J. (2019). Who was poor in the US in 2018?. Washington, DC: Brookings. Retrieved from https://www.brookings.edu/blog/upfront/2019/12/05/who-was-poor-in-the-u-s-in-2018/ 
Cancian, M., \& Haskins, R. (2014). Changes in Family Composition: Implications for Income, Poverty, and Public Policy. The ANNALS of the American Academy of Political and Social Science, 654(1), 31-47. https://doi.org/10.1177/0002716214525322

Cancian, M., \& Reed, D. (2008). Family structure, childbearing, and parental employment: Implications for the level and trend in poverty. University of Wisconsin-Madison, Institute for Research on Poverty.

Conger, R. D., \& Conger, K. J. (2002). Resilience in Midwestern Families: Selected Findings from the First Decade of a Prospective, Longitudinal Study. Journal of Marriage and Family, 64(2), 361-373. https://doi.org/10.1111/j.1741-3737.2002.00361.x

Deutsch, F. (1999). Halving it all: How equally shared parenting works. Harvard University Press.

Dynan, K., Elmendorf, D., \& Sichel, D. (2012). The Evolution of Household Income Volatility. 42.

Finnigan, R. (2018). Varying weekly work hours and earnings instability in the Great Recession. Social Science Research, 74, 96-107. https://doi.org/10.1016/j.ssresearch.2018.05.005

Finnigan, R., \& Hale, J. M. (2018). Working 9 to 5? Union Membership and Work Hours and Schedules. Social Forces, 96(4), 1541-1568. https://doi.org/10.1093/sf/sox101

Fox, L. (2019). “The Supplemental Poverty Measure: 2018.” Washington, DC: U.S. Census Bureau. Retrieved from https://www.census.gov/content/dam/Census/library/publications/2019/demo/p60268.pdf. 
Fox, L., Wimer, C., Garfinkel, I., Kaushal, N., \& Waldfogel, J. (2015). Waging war on poverty: Poverty trends using a historical supplemental poverty measure. Journal of Policy Analysis and Management, 34(3), 567-592.

Gennetian, L. A., Rodrigues, C., Hill, H. D., \& Morris, P. A. (2019). Income Level and Volatility by Children's Race and Hispanic Ethnicity. Journal of Marriage and Family, 81(1), 204229. https://doi.org/10.1111/jomf.12529

Gennetian, L. A., Wolf, S., Hill, H. D., \& Morris, P. A. (2015). Intrayear Household Income Dynamics and Adolescent School Behavior. Demography, 52(2), 455-483. https://doi.org/10.1007/s13524-015-0370-9

Golden, L. (2001). Flexible work schedules: What are we trading off to get them. Monthly Lab. Rev., 124, 50.

Golden, L. (2015). Irregular Work Scheduling and Its Consequences. SSRN Electronic Journal. https://doi.org/10.2139/ssrn.2597172

Gottschalk, P., \& Moffitt, R. (2009). The Rising Instability of U.S. Earnings. Journal of Economic Perspectives, 23(4), 3-24. https://doi.org/10.1257/jep.23.4.3

Gundersen, C., \& Ziliak, J. P. (2003). The Role of Food Stamps in Consumption Stabilization. The Journal of Human Resources, 38, 1051. https://doi.org/10.2307/3558981

Haider, S. J. (2001). Earnings instability and earnings inequality of males in the United States: 1967-1991. Journal of labor Economics, 19(4), 799-836.

Halpern-Meekin, S., Edin, K., Tach, L., \& Sykes, J. (2015). It's not like I'm poor: How working families make ends meet in a post-welfare world. University of California Press.

Hardy, B. L. (2014). Childhood Income Volatility and Adult Outcomes. Demography, 51(5), 1641-1665. https://doi.org/10.1007/s13524-014-0329-2 
Hardy, B. L. (2017). Income instability and the response of the safety net. Contemporary Economic Policy, 35, 312-330.

Hardy, B. L., \& Marcotte, D. E. (2020). Ties that bind? Family income dynamics and children's post-secondary enrollment and persistence. Review of Economics of the Household.

Heflin, C. (2016). Family Instability and Material Hardship: Results from the 2008 Survey of Income and Program Participation. Journal of Family and Economic Issues, 37(3), 359372. https://doi.org/10.1007/s10834-016-9503-6

Hernandez, D. C., \& Ziol-Guest, K. M. (2009). Income Volatility and Family Structure Patterns: Association with Stability and Change in Food Stamp Program Participation. Journal of Family and Economic Issues, 30(4), 357-371.

Hill, H. D., Morris, P., Gennetian, L. A., Wolf, S., \& Tubbs, C. (2013). The Consequences of Income Instability for Children's Well-Being. Child Development Perspectives, 7(2), 8590. https://doi.org/10.1111/cdep.12018

Hill, H. D., Romich, J., Mattingly, M. J., Shamsuddin, S., \& Wething, H. (2017). An Introduction to Household Economic Instability and Social Policy. Social Service Review, 91(3), 371-389. https://doi.org/10.1086/694110

Hill, H. D., \& Ybarra, M. A. (2014). Less-educated workers' unstable employment: Can the safety net help. Fast Focus, 19, 1-5.

Hollister, M. (2011). Employment Stability in the U.S. Labor Market: Rhetoric versus Reality. Annual Review of Sociology, 37(1), 305-324.

Hoynes, H. W., Page, M. E., \& Stevens, A. H. (2006). Poverty in America: Trends and Explanations. Journal of Economic Perspectives, 20(1), 47-68. 
Kalleberg, A. L. (2013). Good jobs, bad jobs: The rise of polarized and precarious employment systems in the United States, 1970s to 2000s (1. papercover ed). Russel Sage Foundation.

Kalleberg, A. L., Reskin, B. F., \& Hudson, K. (2000). Bad Jobs in America: Standard and Nonstandard Employment Relations and Job Quality in the United States. American Sociological Review, 65(2), 256. https://doi.org/10.2307/2657440

LaBriola, J., \& Schneider, D. (2020). Worker Power and Class Polarization in Intra-Year Work Hour Volatility. Social Forces, 98(3), 973-999. https://doi.org/10.1093/sf/soz032

Lambert, S. J. (2008). Passing the buck: Labor flexibility practices that transfer risk onto hourly workers. Human Relations, 61(9), 1203-1227.

Lambert, S. J., Fugiel, P. J., \& Henly, J. R. (2014). Schedule unpredictability among early career workers in the US labor market: A national snapshot. Chicago, IL: Employment Instability, Family Well-being, and Social Policy Network, University of Chicago.

McLanahan, S. (2004). Diverging destinies: How children are faring under the second demographic transition. Demography, 41(4), 607-627.

McLanahan, S. (2009). Fragile Families and the Reproduction of Poverty. The ANNALS of the American Academy of Political and Social Science, 621(1), 111-131.

Moffitt, R. A. (2013). The Great Recession and the Social Safety Net. The ANNALS of the American Academy of Political and Social Science, 650(1), 143-166.

Morduch, J., \& Schneider, R. (2017). The financial diaries: How American families cope in a world of uncertainty. Princeton University Press.

Morduch, J., \& Siwicki, J. (2017). In and Out of Poverty: Episodic Poverty and Income Volatility in the US Financial Diaries. Social Service Review, 91(3), 390-421. 
Morris, P. A., Gennetian, L. A., Hill, H., Tubbs, C., \& Wolf, S. (2012). Income volatility: Trends and implications for families and children, Unpublished manuscript, New York University.

Morrissey, T. W., Cha, Y., Wolf, S., \& Khan, M. (2020). Household economic instability: Constructs, measurement, and implications. Children and Youth Services Review, 118, 105502. https://doi.org/10.1016/j.childyouth.2020.105502

National Academies of Sciences, Engineering, and Medicine (Washington, District of Columbia) (Ed.). (2019). A roadmap to reduce child poverty. The National Academies Press.

Newman, C. (2008). Income volatility and its implications for school lunch. Income volatility and food assistance in the United States, 137-169.

Ruggles, S., Flood, S., Foster, S., Goeken, R., Pacas, J., Schouweiler, M., \& Sobek, M. (2021). IPUMS USA: Version 11.0 [dataset]. Minneapolis, MN: IPUMS. https://doi.org/10.18128/D010.V11.0

Semega, J., Kollar, M., Creamer, J., \& Mohanty, A. (2019). “Income and Poverty in the United States: 2018." Washington, DC: U.S. Census Bureau; U.S. Government Printing Office. Retrieved from https://www.census.gov/content/dam/Census/library/publications/2019/demo/p60266.pdf.

Schmeiser, M. D., Buchholz, D. E., Brown, A. M., Gross, M. B., Larrimore, J. H., Merry, E. A., \& Thomas, L. M. (2014). Report on the economic well-being of US Households in 2013. Retrieved from https://www.federalreserve.gov/econresdata/2013-report-economic-wellbeing-us-households-201407.pdf 
Schneider, D., \& Harknett, K. (2019). Consequences of Routine Work-Schedule Instability for Worker Health and Well-Being. American Sociological Review, 84(1), 82-114. https://doi.org/10.1177/0003122418823184

Shaefer, H. L., \& Edin, K. (2013). Rising Extreme Poverty in the United States and the Response of Federal Means-Tested Transfer Programs. Social Service Review, 87(2), 250-268. https://doi.org/10.1086/671012

Shin, D., \& Solon, G. (2011). Trends in men's earnings volatility: What does the Panel Study of Income Dynamics show? Journal of Public Economics, 95(7-8), 973-982. https://doi.org/10.1016/j.jpubeco.2011.02.007

Short, K., \& Giefer, K. (2013). The Supplemental Poverty Measure in the Survey of Income and Program Participation (SIPP): 2004. Washington, DC: U.S. Census Bureau. Retrieved from https://www.census.gov/content/dam/Census/library/workingpapers/2013/demo/shortgiefer-307930.pdf.

Warren, L., Fox, L., \& Edwards, A. (2020). The Supplemental Poverty Measure in the Survey of Income and Program Participation. Washington, DC: U.S. Census Bureau. Retrieved from https://www.census.gov/content/dam/Census/library/workingpapers/2020/demo/sehsd-wp2020-20.pdf.

Western, B., Bloome, D., Sosnaud, B., \& Tach, L. M. (2016). Trends in income insecurity among US children, 1984-2010. Demography, 53(2), 419-447.

Wimer, C., Parolin, Z., Fenton, A., Fox, L., \& Jencks, C. (2020). The Direct Effect of Taxes and Transfers on Changes in the U.S. Income Distribution, 1967-2015. Demography, 57(5), $1833-1851$. 
Yeung, W. J., Linver, M. R., \& Brooks-Gunn, J. (2002). How Money Matters for Young Children's Development: Parental Investment and Family Processes. Child Development, 73(6), 1861-1879.

Ziliak, J. P., Hardy, B., \& Bollinger, C. (2011). Earnings volatility in America: Evidence from matched CPS. Labour Economics, 18(6), 742-754. 


\section{Tables and Figures}

Table 1. Summary statistics by children's race and ethnicity

\begin{tabular}{|c|c|c|c|c|c|}
\hline & Total & $\begin{array}{l}\text { White } \\
\text { children }\end{array}$ & $\begin{array}{c}\text { Black } \\
\text { children }\end{array}$ & $\begin{array}{l}\text { Hispanic } \\
\text { children }\end{array}$ & $\begin{array}{l}\text { Other } \\
\text { children }\end{array}$ \\
\hline Work-hour volatility & $0.28(0.35)$ & $0.25(0.31)$ & $0.35(0.44)$ & $0.30(0.37)$ & $0.27(0.34)$ \\
\hline OPM poverty & 0.20 & 0.12 & 0.31 & 0.30 & 0.16 \\
\hline SPM poverty & 0.18 & 0.14 & 0.19 & 0.27 & 0.16 \\
\hline Market income (MI) & $\begin{array}{l}72,918.53 \\
(71,345)\end{array}$ & $\begin{array}{c}85,256.32 \\
(78,065)\end{array}$ & $\begin{array}{c}52,027.90 \\
(55,246)\end{array}$ & $\begin{array}{c}53,150.14 \\
(50,762)\end{array}$ & $\begin{array}{c}85,656.28 \\
(79,713)\end{array}$ \\
\hline MI + Cash transfers & $\begin{array}{c}74,023.69 \\
(71,106)\end{array}$ & $\begin{array}{c}86,002.47 \\
(77,871)\end{array}$ & $\begin{array}{c}54,169.17 \\
(54,917)\end{array}$ & $\begin{array}{c}54,403.98 \\
(50,766)\end{array}$ & $\begin{array}{c}86,955.47 \\
(79,561)\end{array}$ \\
\hline MI + Cash transfers + In-kind transfers & $\begin{array}{l}76,071.27 \\
(70,062)\end{array}$ & $\begin{array}{c}87,131.28 \\
(77,202)\end{array}$ & $\begin{array}{c}58,807.39 \\
(53,183)\end{array}$ & $\begin{array}{c}57,103.60 \\
(49,862)\end{array}$ & $\begin{array}{c}88,826.65 \\
(78,532)\end{array}$ \\
\hline MI + Cash + In-kind +/- tax liabilities/refunds & $\begin{array}{c}61,036.09 \\
(44,092)\end{array}$ & $\begin{array}{c}67,270.42 \\
(48,210)\end{array}$ & $\begin{array}{c}51,136.44 \\
(34,299)\end{array}$ & $\begin{array}{c}50,292.33 \\
(333,74)\end{array}$ & $\begin{array}{c}68,621.70 \\
(48,823)\end{array}$ \\
\hline MI + Cash + In-kind +/- tax - expenses & $\begin{array}{c}57,406.48 \\
(43,001)\end{array}$ & $\begin{array}{c}63,199.27 \\
(47,184)\end{array}$ & $\begin{array}{c}47,953.40 \\
(33,471)\end{array}$ & $\begin{array}{c}47,545.10 \\
(32,396)\end{array}$ & $\begin{array}{c}64,490.56 \\
(47,582)\end{array}$ \\
\hline Child's age & $8.49(4.89)$ & $8.50(4.89)$ & $8.53(4.9)$ & $8.50(4.87)$ & $8.34(4.86)$ \\
\hline Child's sex: female & 0.49 & 0.49 & 0.49 & 0.49 & 0.49 \\
\hline Nuclear family & 0.68 & 0.76 & 0.39 & 0.65 & 0.71 \\
\hline Single mother & 0.18 & 0.12 & 0.46 & 0.18 & 0.16 \\
\hline Single mother with partner & 0.04 & 0.03 & 0.04 & 0.05 & 0.04 \\
\hline Single father & 0.05 & 0.04 & 0.06 & 0.05 & 0.05 \\
\hline Single father with partner & 0.03 & 0.02 & 0.04 & 0.05 & 0.03 \\
\hline No biological parents present & 0.02 & 0.01 & 0.02 & 0.02 & 0.02 \\
\hline Less than high school & 0.15 & 0.06 & 0.12 & 0.37 & 0.08 \\
\hline High school & 0.23 & 0.21 & 0.27 & 0.26 & 0.20 \\
\hline Some college & 0.35 & 0.37 & 0.44 & 0.26 & 0.33 \\
\hline College or above & 0.28 & 0.36 & 0.18 & 0.11 & 0.39 \\
\hline Household size & $4.77(1.59)$ & $4.62(1.47)$ & $4.61(1.71)$ & $5.16(1.66)$ & $4.80(1.74)$ \\
\hline Parent's age & $38.58(8.30)$ & $39.03(8.01)$ & $37.81(8.78)$ & $37.61(8.39)$ & $39.73(8.68)$ \\
\hline No change in adult caregivers & 0.88 & 0.89 & 0.85 & 0.86 & 0.87 \\
\hline Both gained and lost adult caregivers & 0.01 & 0.01 & 0.01 & 0.01 & 0.01 \\
\hline Only gained adult caregiver(s) & 0.07 & 0.06 & 0.09 & 0.07 & 0.07 \\
\hline Only lost adult caregiver(s) & 0.05 & 0.04 & 0.05 & 0.05 & 0.05 \\
\hline Professional, management & 0.37 & 0.45 & 0.33 & 0.19 & 0.45 \\
\hline Services related & 0.18 & 0.13 & 0.28 & 0.24 & 0.15 \\
\hline Sales & 0.09 & 0.11 & 0.09 & 0.07 & 0.10 \\
\hline Office & 0.11 & 0.11 & 0.13 & 0.10 & 0.11 \\
\hline Blue-collar jobs & 0.25 & 0.21 & 0.17 & 0.39 & 0.19 \\
\hline $\begin{array}{l}\text { Share of total } \\
\text { Observations }\end{array}$ & 87,508 & $\begin{array}{c}53 \% \\
48,960\end{array}$ & $\begin{array}{c}13 \% \\
11,766\end{array}$ & $\begin{array}{c}25 \% \\
19,170\end{array}$ & $\begin{array}{c}9 \% \\
7,612\end{array}$ \\
\hline
\end{tabular}

Note: Mean (SD) or proportion presented. Data are from SIPP for the period 2004-2016, except for 2008. Workhour volatility is calculated as the standard deviation of the arc percent change of household's total work hours. Family configuration is computed at baseline. The results are weighted using longitudinal calendar year weights. 
Table 2. Summary statistics by a child's family structure

\begin{tabular}{|c|c|c|c|c|c|c|c|}
\hline & Total & $\begin{array}{l}\text { Nuclear } \\
\text { family }\end{array}$ & $\begin{array}{c}\text { Single } \\
\text { mother and } \\
\text { partner }\end{array}$ & $\begin{array}{l}\text { Single } \\
\text { mother }\end{array}$ & $\begin{array}{c}\text { Single } \\
\text { father and } \\
\text { partner }\end{array}$ & $\begin{array}{l}\text { Single } \\
\text { father }\end{array}$ & $\begin{array}{l}\text { Neither } \\
\text { parents } \\
\text { present }\end{array}$ \\
\hline Work-hour volatility & $0.28(0.35)$ & $0.24(0.30)$ & $0.33(0.39)$ & $0.38(0.47)$ & $0.32(0.39)$ & $0.32(0.38)$ & $0.32(0.38)$ \\
\hline OPM poverty & 0.20 & 0.13 & 0.48 & 0.37 & 0.38 & 0.17 & 0.25 \\
\hline SPM poverty & 0.18 & 0.16 & 0.22 & 0.22 & 0.24 & 0.18 & 0.20 \\
\hline Market income (MI) & $\begin{array}{c}72,918.53 \\
(71,345)\end{array}$ & $\begin{array}{c}84,334.64 \\
(779,88)\end{array}$ & $\begin{array}{c}52,715.76 \\
(44,146)\end{array}$ & $\begin{array}{c}42,871.89 \\
(44,303)\end{array}$ & $\begin{array}{c}49,498.29 \\
(39,636)\end{array}$ & $\begin{array}{c}63,453.85 \\
(53,342)\end{array}$ & $\begin{array}{c}59,734.20 \\
(44,441)\end{array}$ \\
\hline MI + Cash transfers & $\begin{array}{c}74,023.69 \\
(71,106)\end{array}$ & $\begin{array}{c}85,177.77 \\
(778,15)\end{array}$ & $\begin{array}{c}54,441.29 \\
(43,845)\end{array}$ & $\begin{array}{c}44,546.56 \\
(44,264)\end{array}$ & $\begin{array}{c}51,078.81 \\
(39,434)\end{array}$ & $\begin{array}{c}64,884.46 \\
(53,168)\end{array}$ & $\begin{array}{c}61,971.84 \\
(44,545)\end{array}$ \\
\hline $\begin{array}{l}\text { MI + Cash transfers + In- } \\
\text { kind transfers }\end{array}$ & $\begin{array}{l}76,071.27 \\
(70,062)\end{array}$ & $\begin{array}{c}86,346.92 \\
(77,142)\end{array}$ & $\begin{array}{c}58,270.35 \\
(42,640)\end{array}$ & $\begin{array}{c}49,058.92 \\
(42,907)\end{array}$ & $\begin{array}{c}54,258.50 \\
(38,467)\end{array}$ & $\begin{array}{c}67,317.88 \\
(52,510)\end{array}$ & $\begin{array}{l}65,085.86 \\
(43,632)\end{array}$ \\
\hline $\begin{array}{l}\text { MI + Cash + In-kind +/- tax } \\
\text { liabilities/refunds }\end{array}$ & $\begin{array}{l}61,036.09 \\
(44,092)\end{array}$ & $\begin{array}{c}67,075.19 \\
(47,698)\end{array}$ & $\begin{array}{l}50,702.73 \\
(29,688)\end{array}$ & $\begin{array}{l}44,694.30 \\
(30,140)\end{array}$ & $\begin{array}{c}48,224.30 \\
(27,172)\end{array}$ & $\begin{array}{r}56,789.55 \\
(37,661)\end{array}$ & $\begin{array}{c}57,063.86 \\
(33,966)\end{array}$ \\
\hline $\begin{array}{l}\mathrm{MI}+\text { Cash + In-kind +/- tax } \\
- \text { expenses }\end{array}$ & $\begin{array}{c}57,406.48 \\
(43,001)\end{array}$ & $\begin{array}{c}63,133.68 \\
(46,543)\end{array}$ & $\begin{array}{c}47,331.47 \\
(28,421)\end{array}$ & $\begin{array}{l}41,898.41 \\
(29,684)\end{array}$ & $\begin{array}{c}45,079.23 \\
(26,761)\end{array}$ & $\begin{array}{c}53,503.62 \\
(36,631)\end{array}$ & $\begin{array}{c}54,462.00 \\
(33,464)\end{array}$ \\
\hline Child's age & $8.49(4.89)$ & $8.41(4.89)$ & $7.55(4.81)$ & $9.11(4.88)$ & $7.10(4.90)$ & $8.73(4.9)$ & $9.19(4.91)$ \\
\hline Child's sex: female & 0.49 & 0.49 & 0.50 & 0.50 & 0.48 & 0.44 & 0.49 \\
\hline White, non-Hispanic & 0.53 & 0.60 & 0.45 & 0.36 & 0.40 & 0.47 & 0.39 \\
\hline Black, non-Hispanic & 0.13 & 0.08 & 0.12 & 0.32 & 0.15 & 0.18 & 0.17 \\
\hline Hispanic & 0.25 & 0.24 & 0.35 & 0.24 & 0.38 & 0.26 & 0.34 \\
\hline Other & 0.09 & 0.09 & 0.08 & 0.08 & 0.07 & 0.09 & 0.10 \\
\hline Less than high school & 0.15 & 0.13 & 0.24 & 0.15 & 0.27 & 0.19 & 0.27 \\
\hline High school & 0.23 & 0.20 & 0.32 & 0.27 & 0.34 & 0.27 & 0.27 \\
\hline Some college & 0.35 & 0.33 & 0.35 & 0.43 & 0.33 & 0.37 & 0.34 \\
\hline College or above & 0.28 & 0.34 & 0.09 & 0.16 & 0.07 & 0.17 & 0.12 \\
\hline Household size & $4.77(1.59)$ & $4.94(1.43)$ & $4.86(1.70)$ & $4.13(1.69)$ & $4.67(1.44)$ & $4.65(2.25)$ & $5.13(2.5)$ \\
\hline Parent's age & $\begin{array}{l}38.58 \\
(8.30)\end{array}$ & $\begin{array}{l}38.80 \\
(7.57)\end{array}$ & $\begin{array}{l}33.18 \\
(7.22)\end{array}$ & $\begin{array}{l}37.99 \\
(9.25)\end{array}$ & $\begin{array}{l}34.90 \\
(7.79)\end{array}$ & $\begin{array}{l}43.16 \\
(9.94)\end{array}$ & $\begin{array}{c}43.56 \\
(12.42)\end{array}$ \\
\hline No change in adult caregivers & 0.88 & 0.90 & 0.83 & 0.84 & 0.89 & 0.77 & 0.81 \\
\hline $\begin{array}{l}\text { Both gained and lost adult } \\
\text { caregivers }\end{array}$ & 0.01 & 0.01 & 0.01 & 0.01 & 0.01 & 0.02 & 0.02 \\
\hline Only gained adult caregiver(s) & 0.07 & 0.06 & 0.06 & 0.11 & 0.04 & 0.12 & 0.09 \\
\hline Only lost adult caregiver(s) & 0.05 & 0.04 & 0.10 & 0.05 & 0.06 & 0.10 & 0.07 \\
\hline Professional, management & 0.37 & 0.41 & 0.26 & 0.33 & 0.18 & 0.28 & 0.23 \\
\hline Services related & 0.18 & 0.14 & 0.25 & 0.29 & 0.20 & 0.19 & 0.26 \\
\hline Sales & 0.09 & 0.09 & 0.10 & 0.10 & 0.07 & 0.09 & 0.11 \\
\hline Office & 0.11 & 0.10 & 0.13 & 0.17 & 0.09 & 0.09 & 0.11 \\
\hline Blue-collar jobs & 0.25 & 0.26 & 0.25 & 0.11 & 0.46 & 0.36 & 0.29 \\
\hline $\begin{array}{l}\text { Share of total } \\
\text { Observations }\end{array}$ & 87,508 & $\begin{array}{c}68 \% \\
58,642\end{array}$ & $\begin{array}{c}4 \% \\
3,534\end{array}$ & $\begin{array}{c}19 \% \\
17,028\end{array}$ & $\begin{array}{c}3 \% \\
2,650\end{array}$ & $\begin{array}{c}5 \% \\
4,091\end{array}$ & $\begin{array}{c}2 \% \\
1,563\end{array}$ \\
\hline
\end{tabular}

Note: Mean (SD) or proportion presented. Data are from SIPP for the period 2004-2016, except for 2008. Workhour volatility is calculated as the standard deviation of the arc percent change of household's total work hours. Family configuration is computed at baseline. The results are weighted using longitudinal calendar year weights. 
Figure 1. Trends in work-hour volatility and child poverty rates

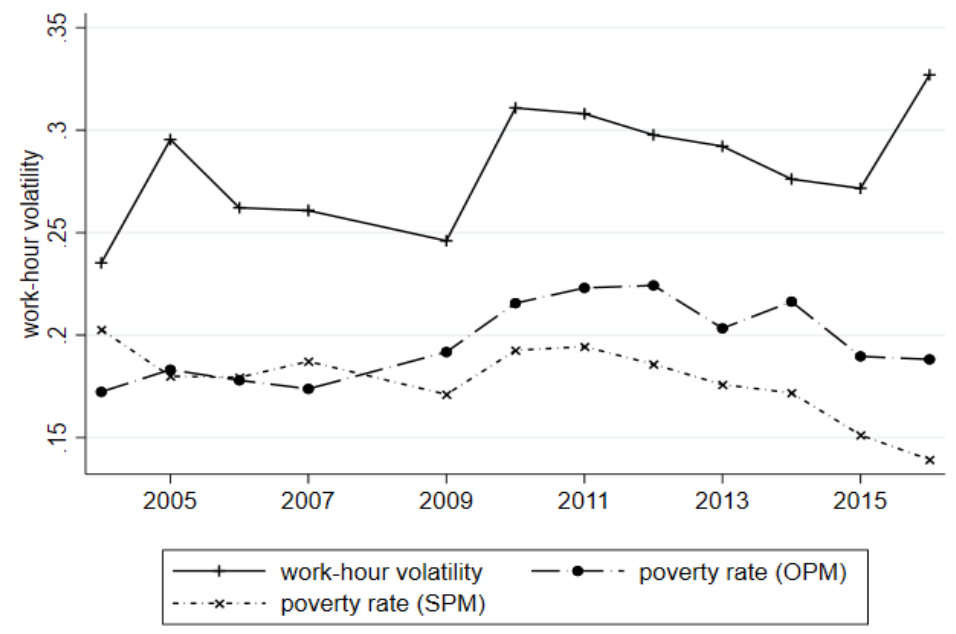

Table 3. Linear regressions predicting children's economic outcomes

\begin{tabular}{|c|c|c|c|c|c|c|}
\hline & Model 1 & Model 2 & Model 3 & Model 4 & Model 5 & Model 6 \\
\hline & $\begin{array}{c}\text { OPM } \\
\text { poverty }\end{array}$ & $\begin{array}{c}\text { SPM } \\
\text { poverty }\end{array}$ & $\begin{array}{l}\text { Market income } \\
\text { (MI) }\end{array}$ & $\mathrm{MI}+\mathrm{Cash}$ & $\begin{array}{c}\mathrm{MI}+\text { Cash + In- } \\
\text { kind }\end{array}$ & $\begin{array}{l}\text { Post-tax, } \\
\text { post-govt. }\end{array}$ \\
\hline Work-hour volatility (ln) & $\begin{array}{c}0.04 * * * * \\
(0.00)\end{array}$ & $\begin{array}{c}0.03 * * * \\
(0.00)\end{array}$ & $\begin{array}{c}-0.15 * * * \\
(0.00)\end{array}$ & $\begin{array}{c}-0.13 * * * \\
(0.00)\end{array}$ & $\begin{array}{c}-0.09 * * * \\
(0.00)\end{array}$ & $\begin{array}{c}-0.07 * * * \\
(0.00)\end{array}$ \\
\hline Black & $\begin{array}{c}0.10 * * * \\
(0.00)\end{array}$ & $\begin{array}{c}0.00 \\
(0.00)\end{array}$ & $\begin{array}{c}-0.16 * * * \\
(0.01)\end{array}$ & $\begin{array}{c}-0.11 * * * \\
(0.01)\end{array}$ & $\begin{array}{l}-0.02 * \\
(0.01)\end{array}$ & $\begin{array}{c}0.02 \\
(0.01)\end{array}$ \\
\hline Hispanic & $\begin{array}{c}0.13 * * * \\
(0.00)\end{array}$ & $\begin{array}{c}0.09 * * * \\
(0.00)\end{array}$ & $\begin{array}{c}-0.33 * * * \\
(0.02)\end{array}$ & $\begin{array}{c}-0.32 * * * \\
(0.02)\end{array}$ & $\begin{array}{c}-0.21 * * * \\
(0.01)\end{array}$ & $\begin{array}{c}-0.14 * * * \\
(0.01)\end{array}$ \\
\hline Others & $\begin{array}{c}0.05^{* * * *} \\
(0.00)\end{array}$ & $\begin{array}{l}0.01 * * \\
(0.00)\end{array}$ & $\begin{array}{c}-0.11 * * * \\
(0.02)\end{array}$ & $\begin{array}{c}-0.08 * * * \\
(0.02)\end{array}$ & $\begin{array}{l}-0.04 * \\
(0.02)\end{array}$ & $\begin{array}{l}-0.01 \\
(0.02)\end{array}$ \\
\hline Single mother, partner & $\begin{array}{c}0.31 * * * \\
(0.01)\end{array}$ & $\begin{array}{c}0.04 * * * \\
(0.01)\end{array}$ & $\begin{array}{c}-0.14 * * * \\
(0.03)\end{array}$ & $\begin{array}{c}-0.10 * * * \\
(0.02)\end{array}$ & $\begin{array}{c}-0.06 * * * \\
(0.02)\end{array}$ & $\begin{array}{c}-0.05^{* *} \\
(0.02)\end{array}$ \\
\hline Single mother & $\begin{array}{c}0.22 * * * * \\
(0.00)\end{array}$ & $\begin{array}{c}0.06 * * * \\
(0.00)\end{array}$ & $\begin{array}{c}-0.49 * * * \\
(0.01)\end{array}$ & $\begin{array}{c}-0.44 * * * \\
(0.01)\end{array}$ & $\begin{array}{c}-0.30 * * * \\
(0.01)\end{array}$ & $\begin{array}{c}-0.19 * * * \\
(0.01)\end{array}$ \\
\hline Single father, partner & $\begin{array}{c}0.20 * * * \\
(0.01)\end{array}$ & $\begin{array}{c}0.05 * * * \\
(0.01)\end{array}$ & $\begin{array}{c}-0.15 * * * \\
(0.03)\end{array}$ & $\begin{array}{c}-0.12 * * * \\
(0.03)\end{array}$ & $\begin{array}{c}-0.07 * * \\
(0.02)\end{array}$ & $\begin{array}{r}-0.04 \dagger \\
(0.02)\end{array}$ \\
\hline Single father & $\begin{array}{c}0.04 * * * \\
(0.01)\end{array}$ & $\begin{array}{c}0.03 * * * \\
(0.01)\end{array}$ & $\begin{array}{c}-0.27 * * * \\
(0.03)\end{array}$ & $\begin{array}{c}-0.23 * * * \\
(0.03)\end{array}$ & $\begin{array}{c}-0.17 * * * \\
(0.02)\end{array}$ & $\begin{array}{c}-0.15 * * * \\
(0.02)\end{array}$ \\
\hline Neither parents present & $\begin{array}{c}0.08^{* * * *} \\
(0.01)\end{array}$ & $\begin{array}{l}0.03 * \\
(0.01)\end{array}$ & $\begin{array}{c}-0.18 * * * \\
(0.04)\end{array}$ & $\begin{array}{c}-0.14 * * * \\
(0.04)\end{array}$ & $\begin{array}{c}-0.11 * * * \\
(0.03)\end{array}$ & $\begin{array}{c}-0.08 * * \\
(0.03)\end{array}$ \\
\hline Child age: $6-12$ & $\begin{array}{r}-0.01 \dagger \\
(0.00)\end{array}$ & $\begin{array}{c}-0.01 * * \\
(0.00)\end{array}$ & $\begin{array}{l}-0.03^{*} \\
(0.01)\end{array}$ & $\begin{array}{l}-0.02 \\
(0.01)\end{array}$ & $\begin{array}{l}-0.03^{*} \\
(0.01)\end{array}$ & $\begin{array}{r}-0.02 \dagger \\
(0.01)\end{array}$ \\
\hline Child age: $13-17$ & $\begin{array}{c}-0.03 * * * \\
(0.00)\end{array}$ & $\begin{array}{c}-0.03 * * * * \\
(0.00)\end{array}$ & $\begin{array}{c}0.06^{* * * *} \\
(0.01)\end{array}$ & $\begin{array}{c}0.07 * * * \\
(0.01)\end{array}$ & $\begin{array}{l}0.03^{*} \\
(0.01)\end{array}$ & $\begin{array}{l}0.03 * * \\
(0.01)\end{array}$ \\
\hline Child sex: female & $\begin{array}{c}0.00 \\
(0.00)\end{array}$ & $\begin{array}{c}0.00 \\
(0.00)\end{array}$ & $\begin{array}{l}-0.00 \\
(0.01)\end{array}$ & $\begin{array}{l}-0.00 \\
(0.01)\end{array}$ & $\begin{array}{l}-0.00 \\
(0.01)\end{array}$ & $\begin{array}{l}-0.00 \\
(0.01)\end{array}$ \\
\hline
\end{tabular}




\begin{tabular}{|c|c|c|c|c|c|c|}
\hline Household size & $\begin{array}{c}0.03 * * * \\
(0.00)\end{array}$ & $\begin{array}{c}0.01 * * * \\
(0.00)\end{array}$ & $\begin{array}{l}-0.00 \\
(0.00)\end{array}$ & $\begin{array}{c}0.01 \\
(0.00)\end{array}$ & $\begin{array}{c}0.02 * * * \\
(0.00)\end{array}$ & $\begin{array}{c}0.04 * * * \\
(0.00)\end{array}$ \\
\hline High school & $-0.09 * * *$ & -0.00 & $0.09 * * *$ & $0.08 * * *$ & -0.00 & $-0.03^{*}$ \\
\hline Some college & $\begin{array}{c}(0.01) \\
-0.16^{* * *} \\
(0.01)\end{array}$ & $\begin{array}{c}(0.01) \\
-0.02 * * \\
(0.01)\end{array}$ & $\begin{array}{l}(0.02) \\
0.33 * * * \\
(0.02)\end{array}$ & $\begin{array}{c}(0.02) \\
0.32 * * * \\
(0.02)\end{array}$ & $\begin{array}{c}(0.02) \\
0.18 * * * \\
(0.02)\end{array}$ & $\begin{array}{c}(0.01) \\
0.11 * * * \\
(0.02)\end{array}$ \\
\hline College or above & $\begin{array}{c}-0.18 * * * \\
(0.01)\end{array}$ & $\begin{array}{c}-0.05^{* * * *} \\
(0.01)\end{array}$ & $\begin{array}{c}0.51 * * * \\
(0.03)\end{array}$ & $\begin{array}{c}0.49^{* * * *} \\
(0.03)\end{array}$ & $\begin{array}{c}0.32 * * * \\
(0.03)\end{array}$ & $\begin{array}{c}0.25 * * * \\
(0.02)\end{array}$ \\
\hline $\begin{array}{l}\text { No change in adult } \\
\text { caregivers }\end{array}$ & $\begin{array}{c}0.03 * * * \\
(0.01)\end{array}$ & $(0.01)$ & $\begin{array}{l}-0.05^{*} \\
(0.03)\end{array}$ & $-0.08 * * *$ & $\begin{array}{c}-0.06 * * * \\
(0.02)\end{array}$ & $-0.09 * * *$ \\
\hline $\begin{array}{l}\text { Both gained and lost adult } \\
\text { caregivers }\end{array}$ & $(0.02)$ & $(0.01)$ & $(0.06)$ & $(0.06)$ & $(0.04)$ & $0.08^{* *}$ \\
\hline $\begin{array}{l}\text { Only gained adult } \\
\text { caregiver(s) }\end{array}$ & $\begin{array}{l}0.00 \\
(0.01)\end{array}$ & $\begin{array}{c}-0.02 * * \\
(0.01)\end{array}$ & $\begin{array}{c}0.16^{* * *} * \\
(0.03)\end{array}$ & $\begin{array}{c}0.12 * * * \\
(0.03)\end{array}$ & $\begin{array}{c}0.08 * * * \\
(0.02)\end{array}$ & $0.07 * * *$ \\
\hline Services related & $\begin{array}{c}0.13^{* * * *} \\
(0.00)\end{array}$ & $\begin{array}{c}0.06^{* * * *} \\
(0.00)\end{array}$ & $\begin{array}{c}-0.45^{* * * *} \\
(0.02)\end{array}$ & $\begin{array}{c}-0.41 * * * \\
(0.01)\end{array}$ & $\begin{array}{c}-0.36^{* * * *} \\
(0.01)\end{array}$ & $\begin{array}{c}-0.26 * * * \\
(0.01)\end{array}$ \\
\hline Sales & $\begin{array}{c}0.07 * * * \\
(0.00)\end{array}$ & $\begin{array}{c}0.04 * * * \\
(0.00)\end{array}$ & $\begin{array}{c}-0.30 * * * \\
(0.02)\end{array}$ & $\begin{array}{c}-0.30 * * * \\
(0.02)\end{array}$ & $\begin{array}{c}-0.26 * * * \\
(0.02)\end{array}$ & $\begin{array}{c}-0.20 * * * \\
(0.02)\end{array}$ \\
\hline Office & $\begin{array}{c}-0.02 * * * \\
(0.00)\end{array}$ & $\begin{array}{c}-0.01 * * \\
(0.00)\end{array}$ & $\begin{array}{c}-0.05 * * * \\
(0.01)\end{array}$ & $\begin{array}{c}-0.07 * * * \\
(0.01)\end{array}$ & $\begin{array}{c}-0.10 * * * \\
(0.01)\end{array}$ & $\begin{array}{c}-0.06 * * * * \\
(0.01)\end{array}$ \\
\hline Blue-collar jobs & $\begin{array}{c}0.07 * * * \\
(0.00)\end{array}$ & $\begin{array}{c}0.05^{* * *} \\
(0.00)\end{array}$ & $\begin{array}{c}-0.45 * * * \\
(0.02)\end{array}$ & $\begin{array}{c}-0.43 * * * \\
(0.02)\end{array}$ & $\begin{array}{c}-0.39 * * * \\
(0.01)\end{array}$ & $\begin{array}{c}-0.30 * * * \\
(0.01)\end{array}$ \\
\hline $\begin{array}{l}\text { State fixed effects } \\
\text { Year fixed effects }\end{array}$ & $\begin{array}{l}\mathrm{x} \\
\mathrm{x}\end{array}$ & $\begin{array}{l}\mathrm{x} \\
\mathrm{x}\end{array}$ & $\begin{array}{l}\mathrm{x} \\
\mathrm{x}\end{array}$ & $\begin{array}{l}\mathrm{x} \\
\mathrm{x}\end{array}$ & $\begin{array}{l}\mathrm{x} \\
\mathrm{x}\end{array}$ & $\begin{array}{l}\mathrm{x} \\
\mathrm{x}\end{array}$ \\
\hline Observations & 87,508 & 87,508 & 87,508 & 87,508 & 87,508 & 87,508 \\
\hline
\end{tabular}

Robust standard errors in parentheses

$* * * \mathrm{p}<0.001, * * \mathrm{p}<0.01,{ }^{*} \mathrm{p}<0.05, \dagger \mathrm{p}<0.10$ 
Figure 2. Percentage of income decline due to work-hours instability that is buffered by government programs (by a child's race and ethnicity)

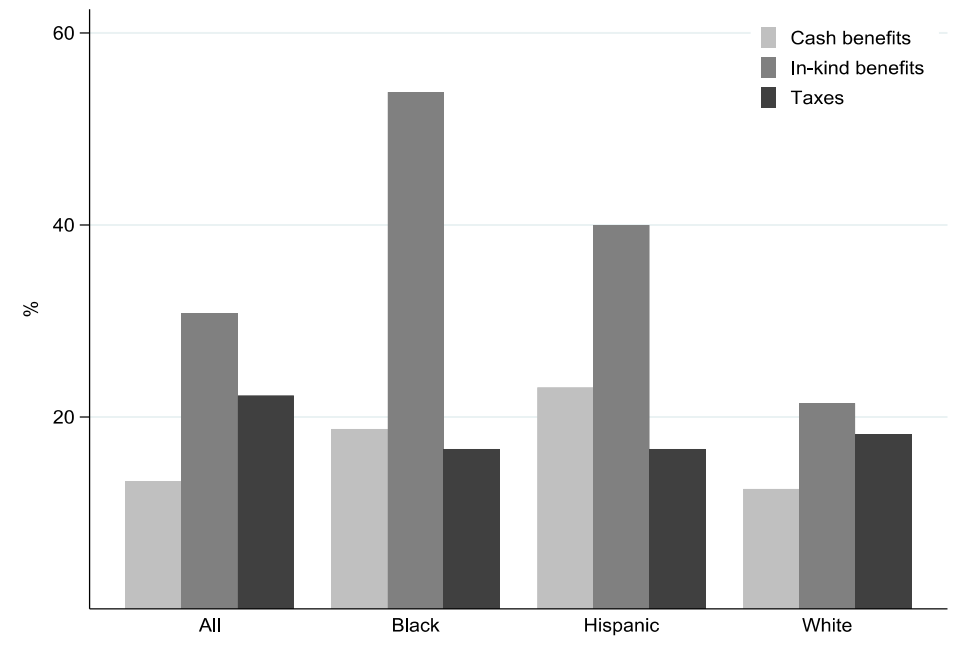

Note: Results are calculated from Appendix Table A3.

Figure 3. Percentage of income decline due to work-hours instability that is buffered by government programs (by a child's family structure)

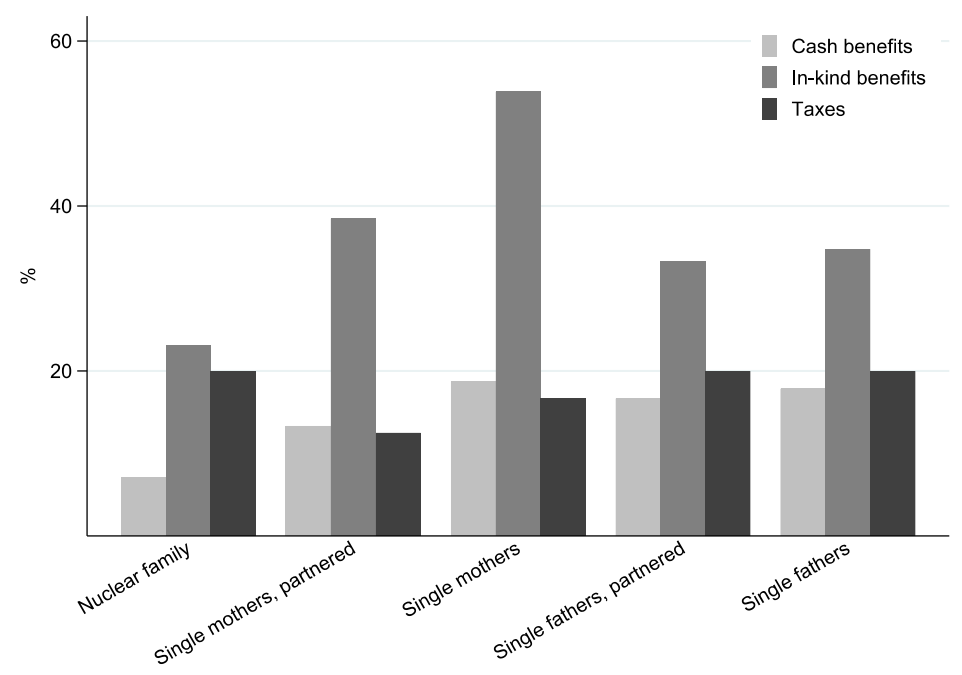

Note: Results are calculated from Appendix Table A4. 


\section{Appendix}

Table A1. Summary statistics by SIPP panels

\begin{tabular}{|c|c|c|c|c|}
\hline & Total & 2004 panel & 2008 panel & 2014 panel \\
\hline Work-hour volatility & $0.28(0.35)$ & $0.26(0.33)$ & $0.29(0.38)$ & $0.29(0.36)$ \\
\hline OPM poverty & 0.20 & 0.18 & 0.21 & 0.21 \\
\hline SPM poverty & 0.18 & 0.19 & 0.19 & 0.16 \\
\hline Market income (MI) & $\begin{array}{c}72,918.53 \\
(71,345)\end{array}$ & $\begin{array}{c}69,464.54 \\
(65,935)\end{array}$ & $\begin{array}{c}67,450.48 \\
(62,260)\end{array}$ & $\begin{array}{c}83,326.69 \\
(84,942)\end{array}$ \\
\hline $\mathrm{MI}+$ Cash transfers & $\begin{array}{c}74,023.69 \\
(71,106)\end{array}$ & $\begin{array}{c}70,476.39 \\
(65,689)\end{array}$ & $\begin{array}{c}68,931.52 \\
(62,053)\end{array}$ & $\begin{array}{c}84,114.49 \\
(84,734)\end{array}$ \\
\hline MI + Cash transfers + In-kind transfers & $\begin{array}{c}76,071.27 \\
(70,062)\end{array}$ & $\begin{array}{c}72,581.94 \\
(64,622)\end{array}$ & $\begin{array}{c}71,253.30 \\
(60,857)\end{array}$ & $\begin{array}{c}85,778.85 \\
(83,865)\end{array}$ \\
\hline MI + Cash + In-kind +/- tax liabilities/refunds & $\begin{array}{c}61,036.09 \\
(44,092)\end{array}$ & $\begin{array}{c}58,332.81 \\
(41,027)\end{array}$ & $\begin{array}{c}59,412.77 \\
(39,852)\end{array}$ & $\begin{array}{c}66,145.65 \\
(51,257)\end{array}$ \\
\hline MI + Cash + In-kind +/- tax - expenses & $\begin{array}{c}57,406.48 \\
(43,001)\end{array}$ & $\begin{array}{c}54,937.08 \\
(40,250)\end{array}$ & $\begin{array}{c}56,270.11 \\
(38,814)\end{array}$ & $\begin{array}{c}61,677.89 \\
(49,894)\end{array}$ \\
\hline Child's age & $8.49(4.89)$ & $8.14(4.69)$ & $8.11(4.93)$ & $9.35(4.64)$ \\
\hline Child's sex: female & 0.49 & 0.49 & 0.49 & 0.49 \\
\hline White, non-Hispanic & 0.53 & 0.56 & 0.54 & 0.49 \\
\hline Black, non-Hispanic & 0.13 & 0.14 & 0.13 & 0.13 \\
\hline Hispanic & 0.25 & 0.22 & 0.25 & 0.28 \\
\hline Other & 0.09 & 0.08 & 0.08 & 0.10 \\
\hline Nuclear family & 0.68 & 0.70 & 0.69 & 0.66 \\
\hline Single mother & 0.18 & 0.18 & 0.18 & 0.19 \\
\hline Single mother with partner & 0.04 & 0.04 & 0.03 & 0.05 \\
\hline Single father & 0.05 & 0.04 & 0.05 & 0.05 \\
\hline Single father with partner & 0.03 & 0.03 & 0.03 & 0.04 \\
\hline No biological parents present & 0.02 & 0.02 & 0.02 & 0.01 \\
\hline Less than high school & 0.15 & 0.16 & 0.15 & 0.14 \\
\hline High school & 0.23 & 0.22 & 0.22 & 0.25 \\
\hline Some college & 0.35 & 0.38 & 0.36 & 0.30 \\
\hline College or above & 0.28 & 0.25 & 0.28 & 0.31 \\
\hline Household size & $4.77(1.59)$ & $4.70(1.49)$ & $4.78(1.62)$ & $4.84(1.67)$ \\
\hline Parent's age & $38.58(8.30)$ & $37.73(8.24)$ & $38.57(8.4)$ & $39.59(8.16)$ \\
\hline No change in adult caregivers & 0.88 & 0.88 & 0.85 & 0.90 \\
\hline Both gained and lost adult caregivers & 0.01 & 0.01 & 0.01 & 0.01 \\
\hline Only gained adult caregiver(s) & 0.07 & 0.06 & 0.09 & 0.05 \\
\hline Only lost adult caregiver(s) & 0.05 & 0.05 & 0.05 & 0.04 \\
\hline Professional, management & 0.37 & 0.34 & 0.38 & 0.41 \\
\hline Services related & 0.18 & 0.17 & 0.19 & 0.17 \\
\hline Sales & 0.09 & 0.11 & 0.09 & 0.08 \\
\hline Office & 0.11 & 0.12 & 0.10 & 0.10 \\
\hline Blue-collar jobs & 0.25 & 0.26 & 0.24 & 0.24 \\
\hline Observations & 87,508 & 31,605 & 33,129 & 22,774 \\
\hline
\end{tabular}

Note: Mean (SD) or proportion presented. The results are weighted using longitudinal calendar year weights. 
Table A2. Detailed sources constituting five versions of a child's household's income package

\begin{tabular}{|c|c|c|}
\hline Market income $(\mathrm{MI})=$ & Earned income + Capital income & (1) \\
\hline $\mathrm{MI}+\mathrm{Cash}=$ & MI + Social security + Unemployment benefits + TANF + GA & (2) \\
\hline $\mathrm{MI}+\mathrm{Cash}+\mathrm{In}-\mathrm{Kind}$ & $\mathrm{MI}+$ Cash + SNAP + Housing assistance + WIC benefit & (3) \\
\hline $\begin{array}{r}\text { Post-tax, post-govt. }= \\
\text { income }\end{array}$ & MI + Cash + In-Kind + Tax benefits - Tax payment & (4) \\
\hline Disposable income (DI) & $\begin{array}{l}\text { Post-tax, post-govt. income - Out-of-pocket medical expense }- \text { Child } \\
\text { care expense }- \text { Work-related expense }- \text { Child support payment }\end{array}$ & (5) \\
\hline
\end{tabular}

Table A3. Linear models predicting children's economic outcomes (by race and ethnicity)

\begin{tabular}{|c|c|c|c|c|}
\hline & $\begin{array}{l}\text { Market income } \\
\text { (MI) }\end{array}$ & $\mathrm{MI}+\mathrm{Cash}$ & $\begin{array}{c}\mathrm{MI}+\text { Cash + } \\
\text { In-kind }\end{array}$ & Post-tax, post-govt. \\
\hline \multicolumn{5}{|l|}{ A: Black children } \\
\hline Work-hour volatility (ln) & $\begin{array}{c}-0.16^{* * * *} \\
(0.01)\end{array}$ & $\begin{array}{c}-0.13 * * * \\
(0.01)\end{array}$ & $\begin{array}{c}-0.06^{* * *} * \\
(0.00)\end{array}$ & $\begin{array}{c}-0.05 * * * \\
(0.00)\end{array}$ \\
\hline Full set of covariates controlled & $\mathrm{x}$ & $\mathrm{x}$ & $\mathrm{X}$ & $\mathrm{x}$ \\
\hline State and year fixed effects & $\mathrm{x}$ & $\mathrm{x}$ & $\mathrm{x}$ & $\mathrm{x}$ \\
\hline \multicolumn{5}{|l|}{ B: Hispanic children } \\
\hline Work-hour volatility (ln) & $\begin{array}{c}-0.13 * * * \\
(0.01)\end{array}$ & $\begin{array}{c}-0.10 * * * \\
(0.01)\end{array}$ & $\begin{array}{c}-0.06 * * * \\
(0.01)\end{array}$ & $\begin{array}{c}-0.05 * * * \\
(0.00)\end{array}$ \\
\hline Full set of covariates controlled & $\mathrm{x}$ & $\mathrm{x}$ & $\mathrm{x}$ & $\mathrm{x}$ \\
\hline State and year fixed effects & $\mathrm{x}$ & $\mathrm{x}$ & $\mathrm{x}$ & $\mathrm{x}$ \\
\hline \multicolumn{5}{|l|}{ C: White children } \\
\hline Work-hour volatility (ln) & $\begin{array}{c}-0.16^{* * * *} \\
(0.01)\end{array}$ & $\begin{array}{c}-0.14 * * * \\
(0.01)\end{array}$ & $\begin{array}{c}-0.11 * * * \\
(0.01)\end{array}$ & $\begin{array}{c}-0.09 * * * \\
(0.00)\end{array}$ \\
\hline Full set of covariates controlled & $\mathrm{X}$ & $\mathrm{x}$ & $\mathrm{x}$ & $\mathrm{x}$ \\
\hline State and year fixed effects & $\mathrm{x}$ & $\mathrm{x}$ & $\mathrm{x}$ & $\mathrm{x}$ \\
\hline \multicolumn{5}{|l|}{ D: Other children } \\
\hline Work-hour volatility $(\ln )$ & $\begin{array}{c}-0.17 * * * \\
(0.01)\end{array}$ & $\begin{array}{c}-0.15 * * * \\
(0.01)\end{array}$ & $\begin{array}{c}-0.10 * * * \\
(0.01)\end{array}$ & $\begin{array}{c}-0.09 * * * \\
(0.01)\end{array}$ \\
\hline Full set of covariates controlled & $\mathrm{X}$ & $\mathrm{x}$ & $\mathrm{x}$ & $\mathrm{x}$ \\
\hline State and year fixed effects & $\mathrm{x}$ & $\mathrm{x}$ & $\mathrm{x}$ & $\mathrm{x}$ \\
\hline
\end{tabular}

Note: Covariates include family structure, child's age, sex, household size, parental age, change in number of adults in households, parental occupation. Sample sizes for panel A =11,766; panel B =19,170; panel $\mathrm{C}=48,960$; panel $\mathrm{D}=7,612$. Robust standard errors in parentheses $* * * \mathrm{p}<0.001, * * \mathrm{p}<0.01, * \mathrm{p}<0.05, \dagger \mathrm{p}<0.10$ 
Table A4. Linear models predicting children's economic outcomes (by family structures)

\begin{tabular}{cccc}
$\begin{array}{c}\text { Market income } \\
(\mathrm{MI})\end{array}$ & $\mathrm{MI}+$ Cash & $\mathrm{MI}+$ Cash + In-kind & $\begin{array}{c}\text { Post-tax, post- } \\
\text { govt. }\end{array}$ \\
\hline$-0.14 * * *$ & $-0.13^{* * *}$ & $-0.10^{* * *}$ & \\
$(0.01)$ & $(0.01)$ & $(0.00)$ & $-0.08 * * *$ \\
$\mathrm{X}$ & $\mathrm{X}$ & $\mathrm{X}$ & $(0.00)$ \\
$\mathrm{x}$ & $\mathrm{x}$ & $\mathrm{x}$ & $\mathrm{x}$ \\
\end{tabular}

B: Single mother, partner

Work-hour volatility (ln)

$-0.15^{* * *}$

$-0.13 * * *$

$-0.08 * * *$

$-0.07 * * *$

Full set of covariates controlled

(0.02)

(0.01)

(0.01)

(0.01)

State and year fixed effects

$\mathrm{x}$

$\mathrm{x}$

$\mathrm{x}$

$\mathrm{X}$

$\mathrm{X}$

$\mathrm{X}$

$\mathrm{X}$

$\mathrm{X}$

\section{C: Single mother}

Work-hour volatility (ln)

$-0.16^{* * *}$
$(0.01)$

$-0.13 * * *$

(0.01)

Full set of covariates controlled

State and year fixed effects

\section{$\mathrm{x}$}

$\mathrm{X}$

$\mathrm{x}$

$\mathrm{X}$

$-0.06 * * *$
$(0.00)$
$\mathrm{x}$
$\mathrm{x}$

$-0.05 * * *$

$(0.00)$

D: Single father, partner

Work-hour volatility (ln)

$\begin{array}{cc}-0.18 * * * & -0.15 * * * \\ (0.02) & (0.02) \\ \mathrm{X} & \mathrm{x} \\ \mathrm{X} & \mathrm{x}\end{array}$

$-0.10 * * *$

(0.01)

$\mathrm{x}$

$\mathrm{x}$

Full set of covariates controlled

State and year fixed effects

$\mathrm{x}$

(0.01)

E: Single father

Work-hour volatility (ln)

\begin{tabular}{cc}
$-0.28 * * *$ & $-0.23 * * *$ \\
$(0.02)$ & $(0.02)$ \\
$\mathrm{X}$ & $\mathrm{X}$ \\
$\mathrm{X}$ & $\mathrm{X}$ \\
\hline
\end{tabular}

$\mathrm{x}$

$\mathrm{x}$

$\mathrm{x}$

Full set of covariates controlled

State and year fixed effects

F: Neither parents present

Work-hour volatility (ln)

$-0.05^{*}$
$(0.03)$

Full set of covariates controlled

State and year fixed effects

$\begin{array}{ll}\mathrm{x} & \mathrm{x} \\ \mathrm{x} & \mathrm{x}\end{array}$

$-0.15 * * *$
$(0.02)$
$\mathrm{X}$
$\mathrm{x}$

$-0.12 * * *$

(0.02)

$\mathrm{X}$
$\mathrm{X}$

Note: Covariates include child's race/ethnicity, child's age, sex, household size, parental age, change in number of adults in households, parental occupation. Sample sizes for panel $\mathrm{A}=58,642$; panel B =3,534; panel $\mathrm{C}=17,028$; panel $\mathrm{D}=2,652$; panel $\mathrm{E}=4,091$; panel $\mathrm{F}=1,563$. Robust standard errors in parentheses $* * * \mathrm{p}<0.001, * * \mathrm{p}<0.01, * \mathrm{p}<0.05, \dagger \mathrm{p}<0.10$ 
Table A5. Linear regressions predicting children's economic outcomes (using alternative measure of work-hour volatility)

\begin{tabular}{|c|c|c|c|c|c|c|}
\hline & $\begin{array}{c}\text { OPM } \\
\text { poverty }\end{array}$ & $\begin{array}{c}\text { SPM } \\
\text { poverty }\end{array}$ & $\begin{array}{c}\text { Market } \\
\text { income (MI) }\end{array}$ & $\begin{array}{l}\mathrm{MI}+ \\
\text { Cash }\end{array}$ & $\begin{array}{l}\text { MI + Cash + } \\
\text { In-kind }\end{array}$ & $\begin{array}{l}\text { Post-tax, } \\
\text { post-govt. }\end{array}$ \\
\hline Work-hour volatility (ln) & $\begin{array}{c}0.04 * * * \\
(0.00)\end{array}$ & $\begin{array}{c}0.03 * * * \\
(0.00)\end{array}$ & $\begin{array}{c}-0.14 * * * \\
(0.00)\end{array}$ & $\begin{array}{c}-0.12 * * * \\
(0.00)\end{array}$ & $\begin{array}{c}-0.08 * * * \\
(0.00)\end{array}$ & $\begin{array}{c}-0.06 * * * \\
(0.00)\end{array}$ \\
\hline Black & $\begin{array}{c}0.10^{* * * *} \\
(0.00)\end{array}$ & $\begin{array}{c}0.00 \\
(0.00)\end{array}$ & $\begin{array}{c}-0.16 * * * \\
(0.01)\end{array}$ & $\begin{array}{c}-0.11 * * * \\
(0.01)\end{array}$ & $\begin{array}{l}-0.02 * \\
(0.01)\end{array}$ & $\begin{array}{c}0.02 \\
(0.01)\end{array}$ \\
\hline Hispanic & $\begin{array}{c}0.13^{* * * *} \\
(0.00)\end{array}$ & $\begin{array}{c}0.09 * * * \\
(0.00)\end{array}$ & $\begin{array}{c}-0.33 * * * \\
(0.02)\end{array}$ & $\begin{array}{c}-0.32 * * * \\
(0.02)\end{array}$ & $\begin{array}{c}-0.21 * * * \\
(0.01)\end{array}$ & $\begin{array}{c}-0.14 * * * \\
(0.01)\end{array}$ \\
\hline Others & $\begin{array}{c}0.05^{* * * *} \\
(0.00)\end{array}$ & $\begin{array}{c}0.01 * * \\
(0.00)\end{array}$ & $\begin{array}{c}-0.11 * * * \\
(0.02)\end{array}$ & $\begin{array}{c}-0.08 * * * \\
(0.02)\end{array}$ & $\begin{array}{l}-0.04^{*} \\
(0.02)\end{array}$ & $\begin{array}{l}-0.02 \\
(0.02)\end{array}$ \\
\hline Single mother, partner & $\begin{array}{c}0.31 * * * \\
(0.01)\end{array}$ & $\begin{array}{c}0.04 * * * \\
(0.01)\end{array}$ & $\begin{array}{c}-0.14 * * * \\
(0.03)\end{array}$ & $\begin{array}{c}-0.11 * * * \\
(0.02)\end{array}$ & $\begin{array}{c}-0.06 * * * \\
(0.02)\end{array}$ & $\begin{array}{c}-0.06^{* * *} \\
(0.02)\end{array}$ \\
\hline Single mother & $\begin{array}{c}0.22 * * * \\
(0.00)\end{array}$ & $\begin{array}{c}0.06 * * * \\
(0.00)\end{array}$ & $\begin{array}{c}-0.49 * * * \\
(0.01)\end{array}$ & $\begin{array}{c}-0.44 * * * \\
(0.01)\end{array}$ & $\begin{array}{c}-0.30 * * * \\
(0.01)\end{array}$ & $\begin{array}{c}-0.19 * * * \\
(0.01)\end{array}$ \\
\hline Single father, partner & $\begin{array}{c}0.20 * * * \\
(0.01)\end{array}$ & $\begin{array}{c}0.05 * * * \\
(0.01)\end{array}$ & $\begin{array}{c}-0.15 * * * \\
(0.03)\end{array}$ & $\begin{array}{c}-0.12 * * * \\
(0.03)\end{array}$ & $\begin{array}{c}-0.06 * * \\
(0.02)\end{array}$ & $\begin{array}{r}-0.04 \dagger \\
(0.02)\end{array}$ \\
\hline Single father & $\begin{array}{c}0.04 * * * \\
(0.01)\end{array}$ & $\begin{array}{c}0.03 * * * \\
(0.01)\end{array}$ & $\begin{array}{c}-0.27 * * * \\
(0.03)\end{array}$ & $\begin{array}{c}-0.23 * * * \\
(0.03)\end{array}$ & $\begin{array}{c}-0.17 * * * \\
(0.02)\end{array}$ & $\begin{array}{c}-0.15^{* * * *} \\
(0.02)\end{array}$ \\
\hline Neither parents present & $\begin{array}{c}0.08^{* * * *} \\
(0.01)\end{array}$ & $\begin{array}{l}0.02^{*} \\
(0.01)\end{array}$ & $\begin{array}{c}-0.17 * * * \\
(0.04)\end{array}$ & $\begin{array}{c}-0.13 * * * \\
(0.04)\end{array}$ & $\begin{array}{c}-0.11 * * * \\
(0.03)\end{array}$ & $\begin{array}{l}-0.08 * \\
(0.03)\end{array}$ \\
\hline Child age: 6-12 & $\begin{array}{l}-0.00 \\
(0.00)\end{array}$ & $\begin{array}{l}-0.01^{*} \\
(0.00)\end{array}$ & $\begin{array}{c}-0.03 * \\
(0.01)\end{array}$ & $\begin{array}{r}-0.02 \dagger \\
(0.01)\end{array}$ & $\begin{array}{c}-0.03^{* *} \\
(0.01)\end{array}$ & $\begin{array}{l}-0.02 * \\
(0.01)\end{array}$ \\
\hline Child age: $13-17$ & $\begin{array}{c}-0.02 * * * \\
(0.00)\end{array}$ & $\begin{array}{c}-0.02 * * * \\
(0.00)\end{array}$ & $\begin{array}{c}0.06 * * * \\
(0.01)\end{array}$ & $\begin{array}{c}0.06^{* * * *} \\
(0.01)\end{array}$ & $\begin{array}{l}0.03 * \\
(0.01)\end{array}$ & $\begin{array}{l}0.03^{*} \\
(0.01)\end{array}$ \\
\hline Child sex: female & $\begin{array}{c}0.00 \\
(0.00)\end{array}$ & $\begin{array}{c}0.00 \\
(0.00)\end{array}$ & $\begin{array}{c}0.00 \\
(0.01)\end{array}$ & $\begin{array}{l}-0.00 \\
(0.01)\end{array}$ & $\begin{array}{l}-0.00 \\
(0.01)\end{array}$ & $\begin{array}{l}-0.00 \\
(0.01)\end{array}$ \\
\hline Household size & $\begin{array}{c}0.03^{* * * *} \\
(0.00)\end{array}$ & $\begin{array}{c}0.01 * * * \\
(0.00)\end{array}$ & $\begin{array}{l}-0.00 \\
(0.00)\end{array}$ & $\begin{array}{c}0.00 \\
(0.00)\end{array}$ & $\begin{array}{c}0.02 * * * \\
(0.00)\end{array}$ & $\begin{array}{c}0.04 * * * \\
(0.00)\end{array}$ \\
\hline High school & $\begin{array}{c}-0.09 * * * \\
(0.01)\end{array}$ & $\begin{array}{l}-0.00 \\
(0.01)\end{array}$ & $\begin{array}{c}0.09 * * * \\
(0.02)\end{array}$ & $\begin{array}{c}0.08 * * * \\
(0.02)\end{array}$ & $\begin{array}{l}-0.00 \\
(0.02)\end{array}$ & $\begin{array}{l}-0.03^{*} \\
(0.01)\end{array}$ \\
\hline Some college & $\begin{array}{c}-0.16 * * * \\
(0.01)\end{array}$ & $\begin{array}{c}-0.02 * * \\
(0.01)\end{array}$ & $\begin{array}{c}0.33 * * * \\
(0.02)\end{array}$ & $\begin{array}{c}0.32 * * * \\
(0.02)\end{array}$ & $\begin{array}{c}0.19^{* * * *} \\
(0.02)\end{array}$ & $\begin{array}{c}0.11 * * * \\
(0.02)\end{array}$ \\
\hline College or above & $\begin{array}{c}-0.18 * * * \\
(0.01)\end{array}$ & $\begin{array}{c}-0.06 * * * \\
(0.01)\end{array}$ & $\begin{array}{c}0.51 * * * \\
(0.03)\end{array}$ & $\begin{array}{c}0.50 * * * \\
(0.03)\end{array}$ & $\begin{array}{c}0.32 * * * \\
(0.03)\end{array}$ & $\begin{array}{c}0.25 * * * \\
(0.02)\end{array}$ \\
\hline No change in adult caregivers & $\begin{array}{c}0.03 * * * \\
(0.01)\end{array}$ & $\begin{array}{c}0.01 \\
(0.01)\end{array}$ & $\begin{array}{l}-0.04 \\
(0.03)\end{array}$ & $\begin{array}{c}-0.06^{* *} \\
(0.02)\end{array}$ & $\begin{array}{c}-0.05^{* *} \\
(0.02)\end{array}$ & $\begin{array}{c}-0.08 * * * \\
(0.02)\end{array}$ \\
\hline $\begin{array}{l}\text { Both gained and lost adult } \\
\text { caregivers }\end{array}$ & -0.00 & $\begin{array}{l}-0.01 \\
(0.01)\end{array}$ & 0.07 & $\begin{array}{c}0.04 \\
(0.06)\end{array}$ & $\begin{array}{l}0.07 \dagger \\
(0.04)\end{array}$ & $\begin{array}{c}0.08 * * \\
(0.03)\end{array}$ \\
\hline Only gained adult caregiver(s) & $\begin{array}{c}0.00 \\
(0.01)\end{array}$ & $\begin{array}{c}-0.02 * * \\
(0.01)\end{array}$ & $\begin{array}{c}0.16^{* * *} \\
(0.03)\end{array}$ & $\begin{array}{c}0.12 * * * \\
(0.03)\end{array}$ & $\begin{array}{c}0.09 * * * \\
(0.02)\end{array}$ & $\begin{array}{c}0.07 * * * \\
(0.02)\end{array}$ \\
\hline Services related & $\begin{array}{c}0.13^{* * * *} \\
(0.00)\end{array}$ & $\begin{array}{c}0.07 * * * \\
(0.00)\end{array}$ & $\begin{array}{c}-0.45 * * * \\
(0.02)\end{array}$ & $\begin{array}{c}-0.42 * * * \\
(0.01)\end{array}$ & $\begin{array}{c}-0.36 * * * \\
(0.01)\end{array}$ & $\begin{array}{c}-0.26 * * * \\
(0.01)\end{array}$ \\
\hline Sales & $\begin{array}{c}0.07 * * * \\
(0.00)\end{array}$ & $\begin{array}{c}0.04 * * * \\
(0.00)\end{array}$ & $\begin{array}{c}-0.30 * * * \\
(0.02)\end{array}$ & $\begin{array}{c}-0.31 * * * \\
(0.02)\end{array}$ & $\begin{array}{c}-0.27 * * * \\
(0.02)\end{array}$ & $\begin{array}{c}-0.20 * * * \\
(0.02)\end{array}$ \\
\hline Office & $\begin{array}{c}-0.02 * * * \\
(0.00)\end{array}$ & $\begin{array}{c}-0.01 * * * \\
(0.00)\end{array}$ & $\begin{array}{c}-0.05 * * * \\
(0.01)\end{array}$ & $\begin{array}{c}-0.06 * * * \\
(0.01)\end{array}$ & $\begin{array}{c}-0.10 * * * \\
(0.01)\end{array}$ & $\begin{array}{c}-0.06 * * * \\
(0.01)\end{array}$ \\
\hline
\end{tabular}


Blue-collar jobs

State fixed effects

Year fixed effects

Observations

Note: Work-hour volatility is measured as coefficient

$$
\begin{array}{cc}
0.08^{* * * *} & 0.05^{* * *} \\
(0.00) & (0.00)
\end{array}
$$

$\mathrm{x}$

$\mathrm{x}$

$\mathrm{x}$

$\mathrm{x}$

87,508

87,508

$* * * \mathrm{p}<0.001, * * \mathrm{p}<0.01, * \mathrm{p}<0.05, \dagger \mathrm{p}<0.10$ 